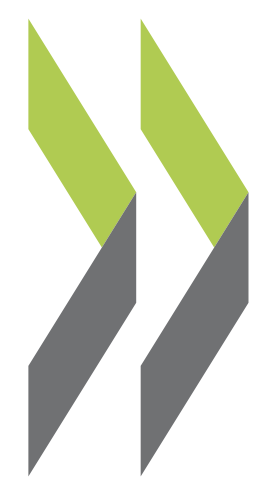

OECD Science, Technology and Industry Working Papers $2004 / 07$

\title{
Human Resources
}

in Science and Technology in India and the International

\section{Binod Khadria}

Mobility of Highly Skilled

Indians 
Organisation de Coopération et de Développement Economiques

DIRECTORATE FOR SCIENCE, TECHNOLOGY AND INDUSTRY

HUMAN RESOURCES IN SCIENCE AND TECHNOLOGY IN INDIA AND THE INTERNATIONAL MOBILITY OF HIGHLY SKILLED INDIANS

STI WORKING PAPER 2004/7

Statistical Analysis of Science, Technology and Industry

Binod Khadria 


\section{STI Working Paper Series}

The Working Paper series of the OECD Directorate for Science, Technology and Industry is designed to make available to a wider readership selected studies prepared by staff in the Directorate or by outside consultants working on OECD projects. The papers included in the series cover a broad range of issues, of both a technical and policy-analytical nature, in the areas of work of the DSTI. The Working Papers are generally available only in their original language - English or French - with a summary in the other.

Comments on the papers are invited, and should be sent to the Directorate for Science, Technology and Industry, OECD, 2 rue André-Pascal, 75775 Paris Cedex 16, France.

The opinions expressed in these papers are the sole responsibility of the author(s) and do not necessarily reflect those of the OECD or of the governments of its member countries.

\section{http://www.oecd.org/sti/working-papers}


DSTI/DOC(2004)7

\title{
HUMAN RESOURCES IN SCIENCE AND TECHNOLOGY IN INDIA AND THE INTERNATIONAL MOBILITY OF HIGHLY SKILLED INDIANS
}

\author{
Binod Khadria*
}

\begin{abstract}
This paper provides estimates of the stocks and flows of human resources in science and technology (HRST) in India, and their breakdown by education and occupation. Furthermore, the paper provides estimates of the number of highly skilled people moving to India and out of India during the 1990s, mainly to the United States. This part of the study also includes a brief, critical overview of Indian concerns on policy matters pertaining to various forms of migration of highly skilled professionals.

Regarding the stocks of highly skilled people in India, the paper estimates that in 1991, between 13 and 16 million people in India could be classified as HRST because of their qualification, a number which had grown to approximately 25 million in 2000 . When expressed as a percentage of the population aged 15-64, this meant an increase of more than one percentage point, from between $2.5 \%$ and $3 \%$ in 1991 to just over 4\% in 2000. In 1991, 10.2 million people could be categorised as HRST because of their occupation. Scientists and engineers, considered to be the core group of the HRST by occupation, accounted for less than $14 \%$ of this total. The number of core HRST, the people that are considered HRST both because of their education and their qualification, amounted to 2.6 million workers in 1991. Recent census data that would allow an update for the year 2001 have not been processed yet, but this is expected before the end of 2004.

One of the indicators of international mobility is provided by the number of Indian students entering the United States during the 1990s. The paper shows that this number has gone up considerably, from around 15000 Indian students in 1990 to almost 50000 in 2001. That the United States is the most favoured destination is proven by the fact that almost $80 \%$ of the Indian students who enrolled in tertiary education in OECD countries in 2001 went to the United States.
\end{abstract}

Another indicator that proves the attractiveness of the United States shows that in 1999, there were 165000 Indian residents in the United States with a science and engineering (S\&E) highest degree. They accounted for $13 \%$ of the total number of foreign-born US residents with S\&E highest degrees, which was more than any other country. India also accounted for a high share of foreign-born residents residing in the United States in 1999 with a science and engineering doctorate, $16 \%$ or 30000 people, second only to China.

\footnotetext{
* Professor of Economics, Zakir Husain Centre for Educational Studies, School of Social Sciences, Jawaharlal Nehru University, New Delhi, India; e-mail: bkhadria@yahoo.com.

The author would like to express his deep appreciation for the valuable research assistance provided by his graduate students Perveen Kumar, Narender Thakur, Geeta Verma, Basant Potnuru, Sridhar Bhagavatula, Durgesh Rai and Kripabar Baruah in the collection and analysis of data. The co-operation of the source agencies, libraries, and their staff members who were approached for access to data is also gratefully acknowledged. Finally, the author would like to express his thanks to Martin Schaaper of the OECD for his many contributions in final editing and presentation of the study. The responsibility for all the possible shortcomings, however, remains with the author.
} 
Moreover, Indians comprised almost $7 \%$ of the total number of people granted entry as permanent residents in the United States in 2001. In the important HRST category of professional and technical occupations, this proportion reached almost $24 \%$ of the world total.

This study was done by an Indian consultant for the OECD, as part of the programme of work of the OECD Centre for Co-operation with Non-Members (CCNM) and the Economic Analysis and Statistics Division (EAS) of the Directorate for Science, Technology and Industry (DSTI). The OECD wishes to thank the National Science Foundation (United States) for its generous support which has facilitated this work and the work on HRST in general. 
DSTI/DOC(2004)7

\title{
RESSOURCES HUMAINES CONSACRÉES À LA SCIENCE ET À LA TECHNOLOGIE EN INDE ET MOBILITÉ INTERNATIONALE DES INDIENS HAUTEMENT QUALIFIÉS
}

\author{
Binod Khadria*
}

\begin{abstract}
Résumé
Ce document fournit des estimations des effectifs et des flux de ressources humaines consacrées à la science et à la technologie (RHST) en Inde, et de leur répartition en fonction de la formation et de la profession. Il donne aussi une estimation des mouvements d'entrée et de sortie du pays des personnes à qualifications élevées dans les années 90, mouvements dirigés essentiellement vers les États-Unis. Cette partie de l'étude comprend également un bref panorama critique des préoccupations suscitées en Inde par l'action publique en rapport avec diverses formes de migration de professionnels hautement qualifiés.

D'après les estimations, l'Inde comptait en 1991 entre 13 et 16 millions de personnes pouvant être considérées comme des RHST du fait de leur qualification; en 2000, ces effectifs atteignaient 25 millions de personnes environ. Exprimée en pourcentage de la population de 15 à 64 ans, cette variation correspond à une hausse d'un point, de $2.5 \%$ à $3 \%$ en 1991 à un peu plus de $4 \%$ en 2000. En 1991, 10.2 millions de personnes pouvaient être considérées comme faisant partie des RHST du fait de leur profession. Les scientifiques et les ingénieurs, qui constituent en principe le groupe principal des RHST par profession, représentaient moins de $14 \%$ de ce total. Les RHST de base, c'est-à-dire les personnels considérés comme des RHST à la fois du fait de leur formation et de leur profession, représentaient 2.6 millions de travailleurs en 1991. Les données récentes de recensement qui permettraient de procéder à une mise à jour pour l'année 2001 n'ont pas encore été traitées, mais devraient l'être avant fin 2004.

Le nombre d'étudiants indiens entrés aux États-Unis dans les années 90 fournit l'un des indicateurs de mobilité internationale. Le document montre que celui-ci a fortement augmenté, passant de 15000 étudiants en 1990 à près de 50000 en 2001. Les États-Unis constituent la destination privilégiée des étudiants indiens, puisque près de $80 \%$ de ceux qui se sont inscrits dans un établissement d'enseignement tertiaire d'un pays de l'OCDE en 2001 ont choisi les États-Unis.

Autre indicateur de l'attrait des États-Unis, 165000 Indiens résidant aux États-Unis en 1999 étaient des scientifiques et des ingénieurs titulaires d'un diplôme de niveau supérieur. Ils représentaient $13 \%$ des résidents des États-Unis nés à l'étranger et titulaires d'un diplôme de niveau supérieur de science ou de sciences de l'ingénieur, pourcentage supérieur à celui de tous les autres pays. L'Inde représentait aussi une part importante des résidents des États-Unis nés à l'étranger et titulaires d'un doctorat en science ou en

Professeur d'économie au Centre Zakir Husain d'études sur l'enseignement, School of Social Sciences, Jawaharlal Nehru University, New Delhi, Inde ; mél : bkhadria@yahoo.com.

L'auteur tient à remercier ses étudiants diplômés Perveen Kumar, Narender Thakur, Geeta Verma, Basant Potnuru, Sridhar Bhagavatula, Durgesh Rai et Kripabar Baruah, pour l'aide précieuse qu'ils lui ont apportée dans la collecte et l'analyse des données utilisées à l'appui de ses recherches. Il exprime aussi toute sa gratitude pour leur coopération aux organismes fournisseurs de données, aux bibliothèques et au personnel avec qui il a pris contact pour obtenir des données. Enfin, l'auteur souhaite exprimer sa reconnaissance à Martin Schaaper, de l'OCDE, pour ses nombreuses contributions à la mise en page et à la présentation finales de l'étude. C'est à l'auteur, cependant, qu'incombe la responsabilité de toutes les imperfections qui pourraient subsister.
\end{abstract}


sciences de l'ingénieur, à savoir $16 \%$ sur un total de 30000 personnes; elle occupait à cet égard la deuxième place après la Chine.

En outre, les Indiens représentaient $7 \%$ de l'ensemble des étrangers ayant obtenu le statut de résident permanent aux États-Unis en 2001. Dans l'importante catégorie des métiers professionnels et techniques des RHST, ce pourcentage atteignait $24 \%$ du total mondial.

Cette étude a été réalisée par un consultant indien auprès de l'OCDE, dans le cadre du programme de travail du Centre pour la coopération avec les non-membres (CCNM) et de la Division des analyses économiques et des statistiques (EAS) de la Direction de la science, de la technologie et de l'industrie (DSTI). L'OCDE remercie la National Science Foundation (Etats-Unis) de tout le soutien qu'elle a apporté à ce projet, ainsi qu'aux travaux sur les RHST en général. 
TABLE OF CONTENTS

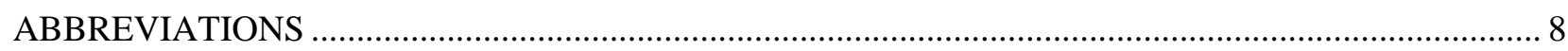

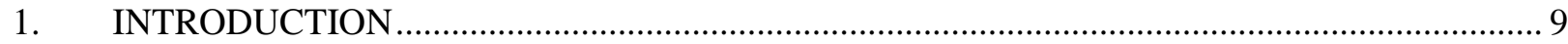

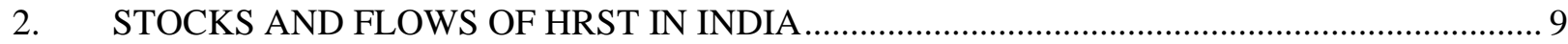

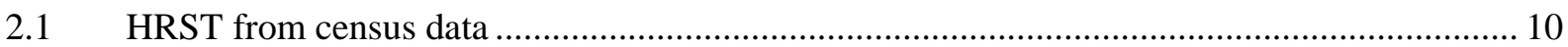

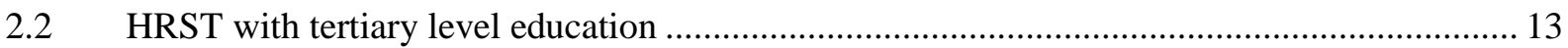

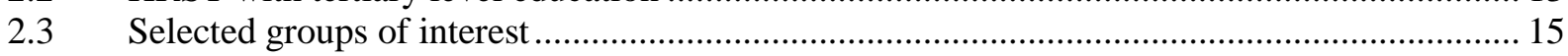

3. INTERNATIONAL MOBILITY OF THE HIGHLY SKILLED …............................................ 22

3.1 Policy concerns in India on international migration of HRST ............................................. 22

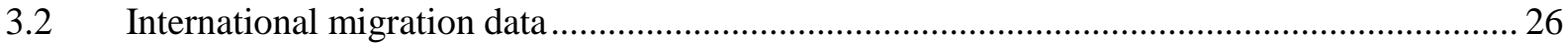

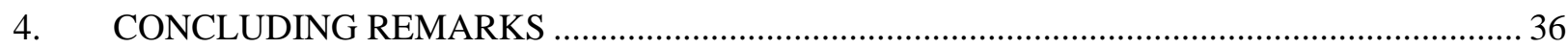

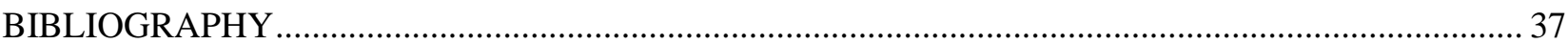

\section{Boxes}

Box 1. Human Resources in Science and Technology (HRST) ......................................................... 11

Box 2. Academic qualification framework - degree structure ............................................................. 13 


\section{ABBREVIATIONS}

AICTE: All India Council for Technical Education

AIU: $\quad$ Association of Indian Universities

CIS: $\quad$ Confederation of Independent States

DGET: Directorate General of Employment and Training

DGHS: Directorate General of Health Services

DST: Department of Science and Technology

FTE: $\quad$ Full-Time Equivalent

GOI: $\quad$ Government of India

HRRD: Human Resources in Research and Development

HRST: $\quad$ Human Resources in Science and Technology

IAMR: Institute of Applied Manpower Research

IIM: Indian Institute of Management

IISc: $\quad$ Indian Institute of Science

IIT: $\quad$ Indian Institute of Technology

IMC: Indian Medical Council

ITES: Information Technology Enabled Services

MCI: $\quad$ Medical Council of India

MHRD: Ministry of Human Resources and Development

NASSCOM: National Association of Software and Service Companies

NCO: National Classification of Occupations

NRI: Non-Resident Indian

NSSO: National Sample Survey Organisation

NTMIS: $\quad$ National Technical Manpower Information System

PIO: $\quad$ Person of Indian Origin

REC: $\quad$ Regional Engineering College

SMC: $\quad$ State Medical Council

SNRC: $\quad$ State Nursing Registration Council

UGC: $\quad$ University Grants Commission 


\section{Introduction}

International mobility of highly skilled people has attracted a considerable amount of attention from policy makers in recent times, both from developed and from developing countries. One of the countries that stands out in these considerations is India, with its large pool of well-trained, English-speaking workers. Just how large this pool is, is the subject of this study, as is the question of how many of these workers are moving abroad for professional reasons.

This paper presents the results of an exercise in the collection and analysis of data on stocks and flows of HRST - as defined in the Canberra Manual (OECD, 1995) - in India (section 2) and their migration from and to India (section 3). The study also includes a brief critical overview of Indian concerns on policy matters pertaining to various traditional as well as newly emerging forms of out-migration and in-migration of highly skilled professionals in India (included in section 3).

Keeping in mind the emerging world labour market for HRST through enhanced international mobility in the $21^{\text {st }}$ century, two particular kinds of migration of highly skilled people, namely the return migration of IT professionals to India, and the changing response of Indian doctors and nurses to the world demand for health workers, have been examined for this study. This was done by means of two specific primary surveys - one of IT professionals in the city of Bangalore and their role in making the city a "corridor" for international mobility of Indian professionals, and the other of health professionals (doctors and nurses) in the city of New Delhi. The results of these surveys are reported in STI Working Paper 2004/6 (Khadria 2004).

\section{Stocks and flows of HRST in India}

This section is broadly designed to estimate the stocks and flows of HRST in India by exploring different available data sources. As the field of HRST is very wide and, in contrast, there is a lack of sufficient data, a three-step strategy has been adopted. First, exploration and collection of data was done from all primary sources (such as census data) and secondary published sources available, while identifying the gaps. In the second stage, an attempt was made to fill the gaps by collecting data directly from source agencies/institutions, e.g. data on doctorate degrees from the Association of Indian Universities, on software engineers from the National Association of Software and Service Companies, on doctors from the Medical Council of India, etc. Finally in the third stage, a compilation of tables was made to arrive at meaningful estimations.

The sources accessed and explored include the documents and publications of the University Grants Commission, the Association of Indian Universities, the Ministry of Human Resources and Development, the Institute of Applied Manpower Research, the Department of Science and Technology, the National Association of Software and Service Companies, the Medical Council of India, the Registrar General of India and other government and autonomous bodies. However, since these sources show great differences in their methods of estimation and classification, utmost care was taken in compiling uniformly featured and reliable tables, so as to avoid double counting and underestimation.

An overview of the sources shows that the whole range of education is divided into (1) general education with the faculties of arts, science, and commerce falling under this category, and (2) professional education, comprising engineering \& technology, medicine, agriculture, veterinary science, education, law and others. Classification on the basis of occupation is not uniform across the sources: some are classified by 'public' and 'private' sector employment, whereas others are classified as 'industrial' or 'institutional' sectors, and still others as agriculture, industry, banking, etc. 
This section has been divided into three parts. The first part analyses in detail the results from past censuses. The second part looks at HRST as defined by the educational qualifications of the workforce, while the last part considers HRST occupations by focusing on selected groups of interest.

\subsection{HRST from census data}

Box 1 provides information on the definition of human resources in science and technology (HRST) and its breakdowns by education and occupation.

By means of background information, in the 20 years between 1981 and 2001, the Indian population grew from 683 million people to just over a billion. In the same period, the labour force grew from 306 million people to 444 million. 


\section{Box 1. Human Resources in Science and Technology (HRST)}

The Canberra Manual (OECD, 1995) defines HRST as people who fulfil one or the other of the following conditions:

they have successfully completed education at the tertiary level in an S\&T field of study;

they are not formally qualified as above, but are employed in an S\&T occupation where the above qualifications are normally required.

The Canberra Manual definition is based both on notions of educational qualification and of occupation and therefore covers a very broad population with either tertiary-level education or an occupation in a field of science and technology (S\&T). S\&T is understood in a very broad sense, covering all fields of education and occupation, including social sciences and humanities. Tertiary level education is defined using the former ISCED definitions:

ISCED category 5: "education at the tertiary level, first stage, of the type that leads to an award not equivalent to a first university degree".

ISCED category 6: "education at the tertiary level, first stage, of the type that leads to a first university degree or equivalent".

ISCED category 7: "education at the tertiary level, second stage, of the type that leads to a postgraduate university degree or equivalent".

ISCED was revised after the release of the Canberra Manual; categories 5B, 5A and 6 of the new ISCED-97 may be considered as the new equivalent of the former categories 5,6 and 7 .

S\&T occupations are defined using the following ISCO-88 categories:

122 Production and operations department managers.

123 Other department managers.

131 General managers.

21 Physical, mathematical and engineering science professionals.

22 Life science and health professionals.

23 Teaching professionals.

24 Other professionals.

31 Physical and engineering science associate professionals.

32 Life science and health associate professionals.

33 Teaching associate professionals.

34 Other associate professionals.

Occupations in India are classified according to the National Classification of Occupations 1968 (NCO 68), which is close to ISCO-68. HRSTO includes certain managerial occupations (122, 123 and 131), which have been defined in ISCO-88, but for which there is no direct conversion to ISCO-68. These occupations are part of division 2 as well as parts of the other divisions in ISCO-68. Therefore, when talking about HRST in this document, managers are excluded, and reference is only made to professionals, technicians and associate professionals (major groups 2 and 3 in ISCO-88, group 0-1 in NCO 68).

The advantage of the double educational/occupational classification is that it allows an analysis of both the supply side of HRST, in terms of qualification (coined with the term HRSTE), and the demand side, in terms of occupation (HRSTO). Its drawback is that, by definition, it does not allow for homogeneous measurement because the two classifications are based on different premises, and it is too broad to meet specific analytical needs. Hence the need to define subsets of interest within this broad population. This was extensively done in the Canberra Manual and has been further refined in subsequent studies.

Source: Auriol and Sexton (2001).

Due to its inherent nature of complete enumeration, data from population censuses provide a unique opportunity to get detailed accounts of the number of HRST in a country. Table 1 presents results from the 1981 and 1991 censuses. Results from the 2001 census are not available yet, but are expected by the end of 2004. Table 1 shows the breakdown of main workers (i.e. ignoring the marginal workers, who accounted 


\section{DSTI/DOC(2004)7}

for $3.3 \%$ of the population in 1981 and for $3.4 \%$ in 1991), by type of occupation, identified in the censuses of 1981 and 1991. The shaded cells in the table represent the various categories of HRST.

According to the census data, in 1981 there were 223 million main workers, of which 7 million (3.2\%) could be classified as HRST because of their occupation (HRSTO) and 6 million (2.7\%) because of their qualification (HRSTE). The overlap between these two categories is called core HRST, which amounted to 2.6 million workers $(1.1 \%)$. In 1991, the number of core HRST had risen to 4.5 million (1.6\%) of the 286 million main workers. In that year, 10.2 million people could be categorised as HRSTO (3.6\%) and 12.8 million as HRSTE (4.5\%). Almost $18 \%$ of core HRST in 1981 were women, a proportion that had grown to $23 \%$ in 1991.

Table 1. Main workers by occupation and level of education, 1981 and 1991 (thousands)

\begin{tabular}{|c|c|c|c|c|c|c|}
\hline \multirow[b]{2}{*}{ Type of occupation (NCO 68) } & \multirow{2}{*}{$\begin{array}{r}\text { non- } \\
\text { HRSTE }\end{array}$} & 1981 & \multirow[b]{2}{*}{ Total } & \multirow{2}{*}{$\begin{array}{r}\text { non- } \\
\text { HRSTE }\end{array}$} & \multirow{2}{*}{$\begin{array}{c}1991 \\
\text { HRSTE }\end{array}$} & \multirow[b]{2}{*}{ Total } \\
\hline & & HRSTE & & & & \\
\hline HRSTO: 0-1. Professional, technical and related & 4493 & 2551 & 7044 & 5700 & 4457 & 10157 \\
\hline 2. Administrative, executive and managerial & 1787 & 578 & 2365 & 1796 & 1127 & 2923 \\
\hline 3. Clerical and related & 5771 & 1559 & 7330 & 6762 & 3005 & 9767 \\
\hline 4. Sales & 9794 & 400 & 10194 & 15251 & 1299 & 16550 \\
\hline 5. Service & 6663 & 86 & 6749 & 8040 & 282 & 8322 \\
\hline 6. Farming, fishing and related & 152434 & 383 & 152817 & 189138 & 1304 & 190442 \\
\hline 7-8-9. Production, transport operators and labourers & 33386 & 312 & 33698 & 43317 & 1079 & 44396 \\
\hline 10. Workers not classified by occupation & 2214 & 106 & 2320 & 3131 & 244 & 3375 \\
\hline Total & 216542 & 5975 & 222517 & 273134 & 12797 & 285931 \\
\hline
\end{tabular}

Note: Excluding data for Jammu and Kashmir.

Source: Government of India, Registrar general of India, 1991 Census.

A further breakdown of the professional, technical and related occupations (HRSTO) in 1991 reveals that the majority of these people were teachers (see Figure 1). With around one third female teachers, this group also had the highest share of women. Scientists and engineers on the other hand, considered to be the core group of HRSTO, accounted for less than 14\% of total HRSTO, of which only $9 \%$ were women.

Figure 1. HRST by occupation, 1991 (thousands)

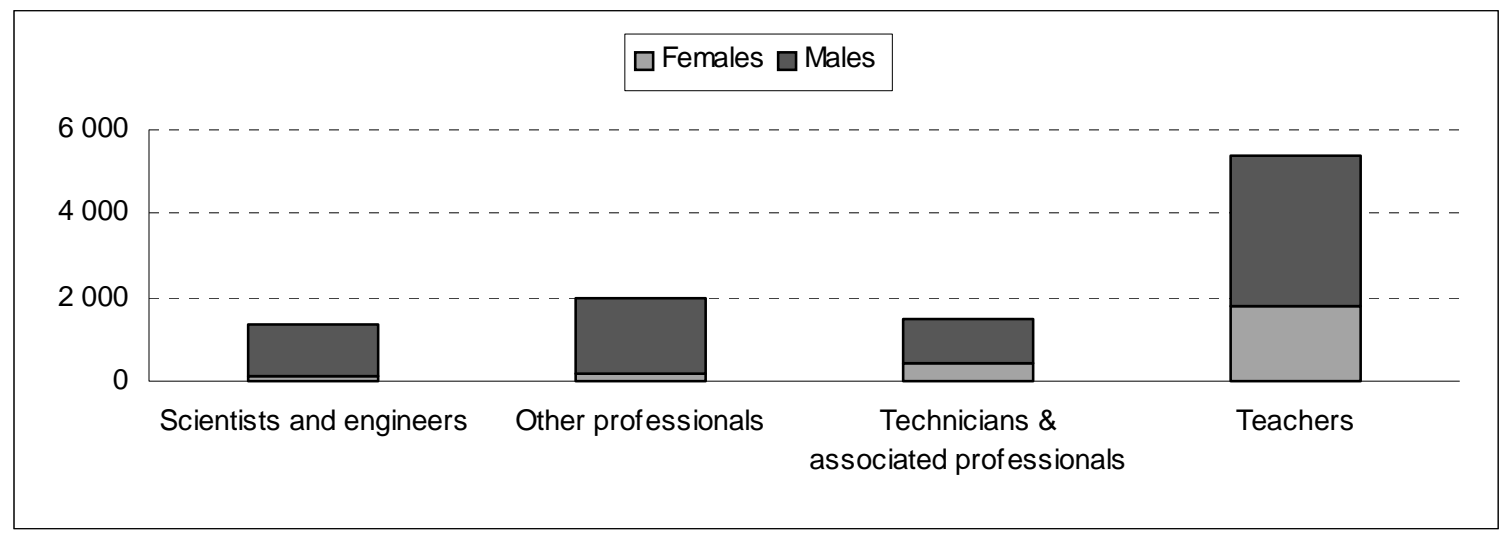

Note: Excluding data for Jammu and Kashmir.

Source: Government of India, Registrar General of India, 1991 Census. 


\subsection{HRST with tertiary level education}

The educational system in India grew at rapid speed during the 1990s, with a vast increase in the number of recognised institutions for higher education. The number of universities (including deemed universities and institutions of national importance) stood at 254 in the year 2000-2001, up from 184 in the year 1990-1991. The number of colleges for general education went up from 4862 to 7929 , while the number of colleges for professional education went up from 886 to 2223 . Information on the academic degree structure can be found in Box 2.

\section{Box 2. Academic qualification framework - degree structure}

There are three principal levels of qualification within the higher education system in India. These are:

Bachelor/undergraduate level

Master's/postgraduate level

Doctoral/pre-doctoral level

Diploma courses are also available at the undergraduate and postgraduate level. At the undergraduate level, the length of these courses varies between one and three years, while postgraduate diplomas are normally awarded after one year's study.

Bachelor's degrees in arts, commerce and sciences require three years of education (after 12 years of school education). In some places there are honours and special courses available. These are not necessarily longer in duration but indicate greater depth of study. Bachelor degrees in the professional fields of study of agriculture, dentistry, engineering, pharmacy, technology and veterinary medicine generally take four years, while architecture and medicine take five and five and a half years respectively. Other bachelor degrees - in education, journalism and librarianship - are second degrees. A bachelor's degree in law can either be taken as an integrated degree lasting five years or as a three-year course as a second degree.

The Master's degree is normally of two-year's duration. It is either based on course-work without a thesis or it is based on research alone.

A pre-doctoral programme, Master of Philosophy (M.Phil.), is taken after completion of the Master's degree. This can either be completely research based or can include course work as well. PhDs are awarded two years after the M.Phil. or three years after the Master's degree (although it generally takes longer). Students are expected to write a substantial thesis based on original research.

Source: Ministry of Education Web site (http://www.education.nic.in/htmlweb/edusta.htm)

Enrolments in higher education also increased considerably in the 1990s, from 5.3 million in 1991-92 to 7.7 million in 1999-2000, distributed over the various fields of study as listed in Table 2. 
Table 2. Enrolments in higher education, by field of study (thousands)

\begin{tabular}{|l|r|r|r|r|r|r|}
\hline & $\mathbf{1 9 9 1 - 9 2}$ & $\mathbf{1 9 9 5 - 9 6}$ & $\mathbf{1 9 9 6 - 9 7}$ & $\mathbf{1 9 9 7 - 9 8}$ & $\mathbf{1 9 9 8 - 9 9}$ & $\mathbf{1 9 9 9 - 0 0}$ \\
\hline General education & & & & & & \\
\hline Natural sciences & 1034 & 1260 & 1324 & 1387 & 1454 & 1477 \\
\hline Social sciences & 1155 & 1410 & 1479 & 1550 & 1625 & 1694 \\
\hline Humanities & 2129 & 2593 & 2729 & 2860 & 2997 & 3136 \\
\hline Professional courses & & & & & & \\
\hline Engineering and technology & 258 & 316 & 331 & 347 & 363 & 389 \\
\hline Medical sciences & 179 & 220 & 230 & 241 & 252 & 271 \\
\hline Agricultural sciences & 55 & 68 & 74 & 78 & 82 & 81 \\
\hline Veterinary Sciences & 13 & 16 & 20 & 21 & 22 & 23 \\
\hline Education & 121 & 148 & 155 & 163 & 171 & 178 \\
\hline Law & 279 & 342 & 358 & 375 & 393 & 402 \\
\hline Others & 42 & 52 & 54 & 57 & 59 & 83 \\
\hline Total & $\mathbf{5 2 6 6}$ & $\mathbf{6 4 2 6}$ & $\mathbf{6 7 5 5}$ & $\mathbf{7 0 7 8}$ & $\mathbf{7 4 1 8}$ & $\mathbf{7 7 3 4}$ \\
\hline
\end{tabular}

Note: The Institute of Applied Manpower Research, citing the Ministry of Human Resources and Development, estimates the number of enrolments in general education at about 800000 persons higher in 1999-2000.

Source: University Grants Commission (UGC), cited in Research and Development Statistics 2000-2001 (DST 2002).

Table 3 gives estimated stock figures of people with completed higher education, the so-called HRSTE. It covers all of the higher education system, except for professional post-graduates, for which data are not available. The first three rows represent the ISCED 5 level (based on ISCED-97), while the fourth row relates to ISCED level 6. No distinction can be made between ISCED 5A and 5B, because of the way degrees are awarded in India. The main source of data is the Institute of Applied Manpower Research (IAMR), which has estimated the stock of various categories of manpower. The estimated stock figures are, in general, the extension of the 1981 stock estimates, which are based on census data. The same set of assumptions and attrition rates has been used in these reports. The outflow figures are worked out by applying appropriate wastage/stagnation rates to the estimated enrolment at different levels of education. The definition of attrition as applied by the IAMR is the "diminution in the stock of manpower as a result of death, retirement and net out-migration. However, attrition rates relating to an occupational category must also take into account their mobility to other occupations".

Table 3 shows that the stock of HRSTE increased from 15.6 million people in 1991 to 25.2 million in 2000. Expressed as a percentage of the population aged 15-64, the proportion of HRSTE grew from $3.0 \%$ to $4.1 \%$. The largest growth was found in the doctorate degree holders, which is the group that accounts for the lowest share of the total.

Table 3 uses 1981 census data as a base from which future stocks are estimated, including for the year 1991 and beyond when there was another census. According to data from the 1991 census, there were 12.8 million workers with a graduate degree or higher, while Table 3 gives a stock estimate of 15.6 million people with higher education. The difference between the two figures can be explained by two factors: 1) graduate unemployment ("non-workers") and employment of people as so-called "marginal workers", and 2) by 'estimation error' in the projections. The same would hold true for the 2000 estimates when the actual figures from the 2001 census become available. 
Table 3. Stock of people with higher education degrees (thousands)

\begin{tabular}{|c|c|c|c|c|c|c|c|c|c|c|}
\hline & 1991 & 1992 & 1993 & 1994 & 1995 & 1996 & 1997 & 1998 & 1999 & 2000 \\
\hline Graduates in general education & 10400 & 11037 & 11702 & 12588 & 13038 & 13716 & 14420 & 15180 & 15980 & 16804 \\
\hline Graduates in professional education & 2077 & 2190 & 2316 & 2432 & 2528 & 2759 & 2910 & 3063 & 3213 & 3105 \\
\hline Post-graduates in general education & 3071 & 3276 & 3491 & 3718 & 3962 & 4220 & 4489 & 4765 & 5041 & 5327 \\
\hline Doctorate degree holders & 39 & - & 48 & 58 & - & 68 & 79 & 90 & 101 & - \\
\hline Total & 15587 & 16629 & 17558 & 18795 & 19527 & 20763 & 21898 & 23098 & 24334 & 25237 \\
\hline
\end{tabular}

Notes: Professional post-graduates data are not available. Stock of doctorate degree holders (and hence the total) is underestimated, because data for various years are missing (1983-84, 1985-86, 1987-88, 1989-90, 1991-92,1994-95). Totals for 1992, 1995 and 2000 do not include the stock of doctorate degree holders. Stocks as of the beginning of the year.

Source: Compiled by the author from data from IAMR and UGC.

\subsection{Selected groups of interest}

Doctorate degree holders

Table 4 provides more detail about PhD graduates. Between 1990-91 and 1998-99, the number of doctorate degrees awarded rose from more than 8000 to almost 11000 , an increase of $30.6 \%$. The two largest categories, natural sciences and humanities - together accounting for almost three quarters of all awarded doctorates - grew at the same rate as the total.

Table 4. Number of doctorate degrees awarded by field of study

\begin{tabular}{|l|r|r|r|r|r|r|r|r|r|r|}
\hline Faculty & $\mathbf{9 0 - 9 1}$ & $\mathbf{9 1 - 9 2}$ & $\mathbf{9 2 - 9 3}$ & $\mathbf{9 3 - 9 4}$ & $\mathbf{9 4 - 9 5}$ & $\mathbf{9 5 - 9 6}$ & $\mathbf{9 6 - 9 7}$ & $\mathbf{9 7 - 9 8}$ & $\mathbf{9 8 - 9 9}$ & $\begin{array}{r}\text { Growth } \\
\mathbf{9 0 - 9 8}(\mathbf{\%})\end{array}$ \\
\hline Natural sciences & 2950 &.. & $3 \mathbf{3 8 6}$ & $\mathbf{3 4 6 7}$ &.. & 3861 & $3 \mathbf{4 9 8}$ & $3 \mathbf{8 9 4}$ & 3836 & 30.0 \\
\hline Social sciences & 290 &.. & 453 & 515 &.. & 612 & 502 & 541 & 541 & 86.6 \\
\hline Humanities & 3210 &.. & 3621 & 4039 &.. & 3957 & 4245 & 4058 & 4189 & 30.5 \\
\hline Engineering and techn. & 629 &.. & 323 & 329 &.. & 374 & 298 & 744 & 696 & 10.7 \\
\hline Medical sciences & 140 &.. & 116 & 145 &.. & 135 & 133 & 200 & 190 & 35.7 \\
\hline Agricultural sciences & 715 &.. & 611 & 769 &.. & 780 & 968 & 849 & 785 & 9.8 \\
\hline Veterinary sciences & 145 &.. & 112 & 114 &.. & 138 & 152 & 122 & 101 & -30.3 \\
\hline Education & 188 &.. & 247 & 308 &.. & 295 & 295 & 342 & 310 & 64.9 \\
\hline Law & 51 &.. & 72 & 73 &.. & 75 & 65 & 67 & 75 & 47.1 \\
\hline Others & 65 &.. & 129 & 164 &.. & 170 & 252 & 249 & 228 & 250.8 \\
\hline Total & $\mathbf{8 3 8 3}$ &.. & $\mathbf{9 0 7 0}$ & $\mathbf{9 9 2 3}$ &.. & $\mathbf{1 0 ~ 3 9 7}$ & $\mathbf{1 0 ~ 4 0 8}$ & $\mathbf{1 1 0 6 6}$ & $\mathbf{1 0} \mathbf{9 5 1}$ & $\mathbf{3 0 . 6}$ \\
\hline
\end{tabular}

Note: Data for 1998-99 are provisional.

Source: UGC, compiled by the Department of Science and Technology (DST 2002). 
Science and Technology $(S \& T)$ personnel

The IAMR also publishes estimates of stocks of S\&T personnel, where S\&T personnel includes selected professional graduates in medical, agricultural and veterinary sciences, degree and diploma holders in engineering ${ }^{1}$, and graduates and post-graduates in general sciences. Table 5 shows the results for selected years. Between 1991 and 2000, the stock of S\&T personnel grew by 60\%, from 4.8 million people to 7.7 million. Almost half of these people were graduates from science studies (such as mathematics, chemistry, biology and physics), while the largest growth rates were reported for engineers.

Table 5. Estimated stock of S\&T personnel, beginning of the year (thousands)

\begin{tabular}{|l|r|r|r|r|r|}
\hline Category & $\mathbf{1 9 9 1}$ & $\mathbf{1 9 9 6}$ & $\mathbf{1 9 9 8}$ & $\mathbf{1 9 9 9}$ & $\mathbf{2 0 0 0}$ \\
\hline Engineering degree holders & 547 & 705 & $\mathbf{7 9 8}$ & 846 & 970 \\
\hline Engineering diploma holders & 874 & 1138 & 1256 & 1313 & 1456 \\
\hline Medical graduates (including dental surgeons) & 310 & 358 & 380 & 392 & 403 \\
\hline Agricultural graduates & 168 & 202 & 217 & 224 & 231 \\
\hline Veterinary graduates & 34 & 40 & 43 & 44 & 45 \\
\hline Science graduates & 2430 & 3155 & 3479 & 3655 & 3838 \\
\hline Science post-graduates & 482 & 626 & 696 & 731 & 767 \\
\hline Total & $\mathbf{4 8 4 6}$ & $\mathbf{6 2 2 5}$ & $\mathbf{6 8 6 8}$ & $\mathbf{7 2 0 4}$ & $\mathbf{7 7 1 0}$ \\
\hline
\end{tabular}

Note: Data for 1999 and 2000 are projections.

Source: IAMR, New Delhi, cited in: Research and Development Statistics 2000-2001, p.88 (DST 2002).

\section{Human Resources in R\&D (HRRD)}

R\&D data have been collected for some time in India. Since 1973-74, the Department of Science and Technology has been conducting national surveys on the resources deployed for scientific and technological activities, following UNESCO recommendations (DST, 2002). Currently, R\&D expenditure, as defined by the Frascati Manual (OECD, 2002), forms an integral part of this data collection. Although the coverage is not complete, for example the higher education sector and small enterprises are not covered, these data shed light on an important part of the HRST population, namely the human resources in R\&D (HRRD).

After an increase from 123000 to 203000 of personnel employed in R\&D establishments between 1980 and 1990, Figure 2 shows volatile behaviour in the 1990s. After a small decrease between 1990 and 1992 and a steady increase between 1992 and 1996, there was a significant drop in R\&D personnel between 1996 and 1998, especially in the important group of researchers.

1. Concerning the difference between degrees and diplomas, degrees are awarded only by universities and a few institutions of national importance, such as the Indian Institute of Technology (IITs), whereas diplomas are awarded by both universities and other educational institutions (such as Industrial Training Institutes - ITIs - or polytechnics, which provide vocational education). However, diplomas awarded by institutions other than universities may be equally prestigious or even higher than university degrees when awarded by institutions of national importance. For example, the Indian Institute of Management (IIM) awards Post-Graduate Diplomas in Business Management (PGDBM), whereas the University of New Delhi awards a degree of Master of Business Administration (MBA), but the former is rated higher than the latter. Within universities, diplomas are awarded for short-term or part-time courses compared to degrees, which are longer-term/full-time courses. Open Universities are an exception in terms of providing degrees through part-time/long-term courses, but they also award short-term/part-time diplomas and 'Certificate' (not a degree) courses. 
Figure 2. Personnel employed in R\&D establishments (thousands of FTEs)

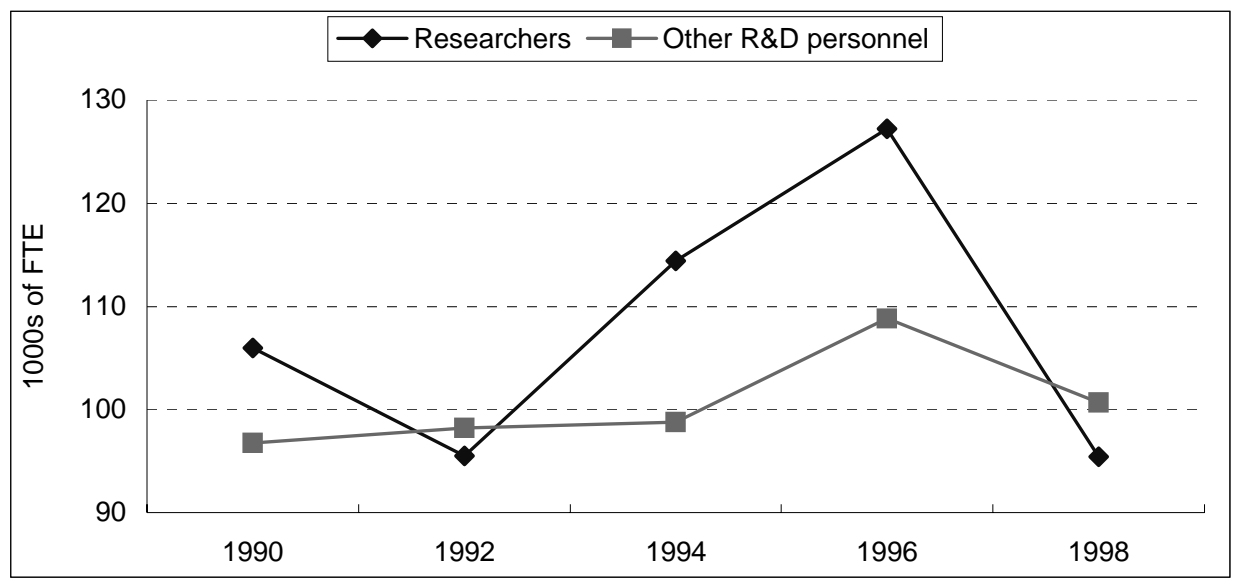

Note: Excluding data for the higher education sector and small scale industries.

Source: Data collected and compiled by the Department of Science and Technology (DST 2002).

In 1998, there were 95000 researchers in the business enterprise sector (excluding small scale industries) and government sector combined, of which just over one-third in the business sector (see Table 6). Technicians and other supporting R\&D personnel numbered 101000 , of which just over one fifth in the business sector. In all cases, about $10 \%$ of the people were female.

Table 6. Personnel employed in R\&D establishments, 1998 (thousands of FTEs)

\begin{tabular}{|l|r|r|r|r|r|r|r|r|}
\hline & \multicolumn{2}{|c|}{ Researchers } & \multicolumn{2}{|c|}{ Other R\&D personnel } & \multicolumn{2}{|c|}{ Adm. personnel } & \multicolumn{2}{|c|}{ Total } \\
\hline & Total & \% Fem. & Total & \% Fem. & Total & \% Fem. & Total & $\%$ Fem. \\
\hline Business enterprise sector & 35 & 9.7 & 21 & 11.3 & 13 & 17.1 & 70 & 11.6 \\
\hline Government sector & 60 & 10.4 & 79 & 9.8 & 99 & 15.7 & 239 & 12.4 \\
\hline Higher education sector &.. & &.. & &.. & &.. & \\
\hline Total (excl. higher education sector) & 95 & 10.2 & 101 & 10.1 & 112 & 15.9 & 308 & 12.2 \\
\hline
\end{tabular}

Note: Data for the business enterprise sector do not include small scale industries.

Source: Data collected and compiled by the Department of Science and Technology (DST 2002).

For the year 1996, a further breakdown is available for just over half of the researchers (see Figures 3 and 4). From these figures it can be seen that a quarter of researchers had a PhD degree. In terms of field of specialisation, almost half of the researchers were working in engineering and technology, followed by $26 \%$ in natural sciences and $20 \%$ in agricultural sciences. 

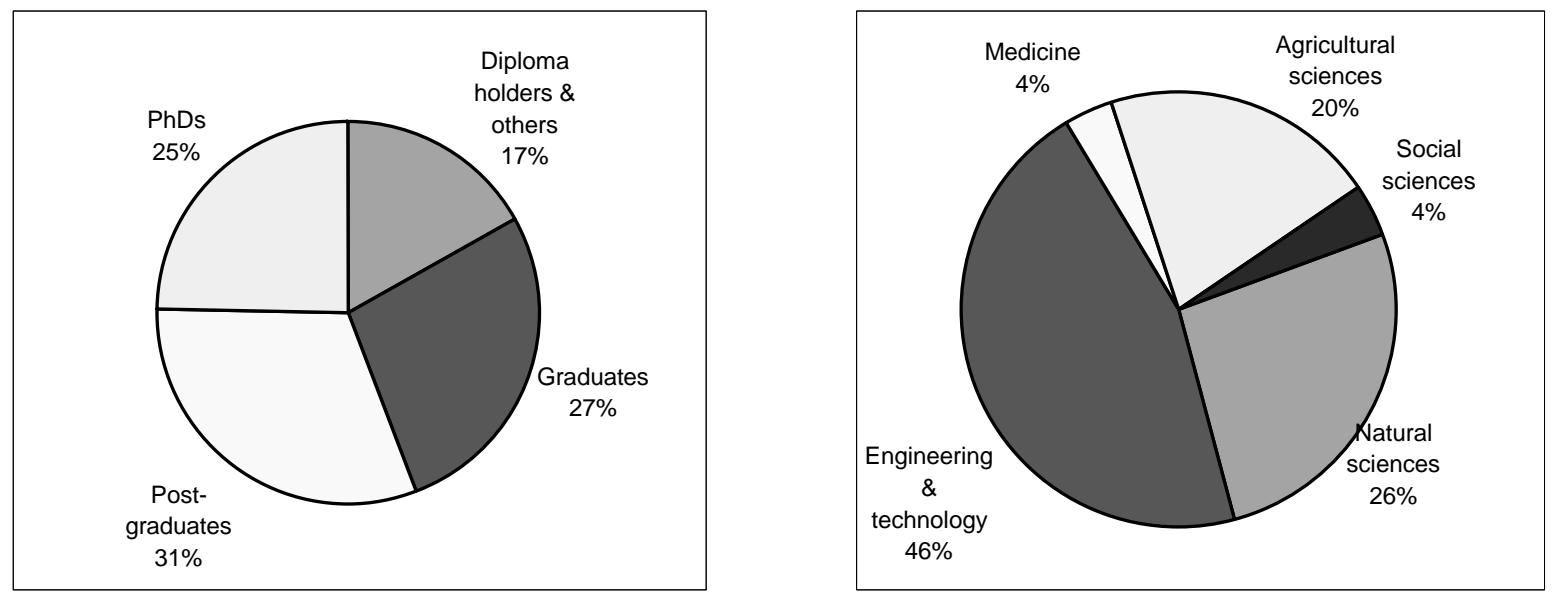

Note: Only data for which break-down is available are reported; the higher education sector is excluded.

Source: Department of Science and Technology (DST 2002).

\section{IT personnel}

The national classification of occupations, NCO 68, stems from 1968, and is therefore too old to contain useful information about IT occupations. However, data are available through NASSCOM, the National Association of Software and Service Companies.

Table 7 shows the employment of IT professionals, broken down by activity. It shows that the number of IT professionals has increased almost tenfold over 10 years.

Table 7. Professionals employed in the Indian IT sector (thousands)

\begin{tabular}{|l|r|r|r|r|r|}
\hline & $\mathbf{1 9 9 0 - 9 1}$ & $\mathbf{1 9 9 6 - 9 7}$ & $\mathbf{1 9 9 9 - 0 0}$ & $\mathbf{2 0 0 0 - 0 1}$ & $\mathbf{2 0 0 1 - 0 2}$ \\
\hline Software exports sector & & & 110 & 162 & 170 \\
\hline Software domestic sector & & & 17 & 20 & 22 \\
\hline Software - captive in user organisation & & & 115 & 178 & 224 \\
\hline IT enabled services (ITES) & & & 42 & 70 & 106 \\
\hline Total & $\mathbf{5 6}$ & $\mathbf{1 0 6}$ & $\mathbf{2 8 4}$ & $\mathbf{4 3 0}$ & $\mathbf{5 2 2}$ \\
\hline
\end{tabular}

Note: Data for 2001-02 are estimated.

Source: NASSCOM (2002).

Table 8 forecasts India's new IT labour supply, where new IT labour includes the categories of IT professionals, non-IT professionals being trained in degree and diploma colleges and IT labour in non-engineering fields. The new IT labour figures are based on supply from engineering colleges. The terminal-year enrolments in degree and diploma colleges for producing the IT- and non-IT professionals and IT labour in the subsequent years have been projected to increase from 133000 in 2000-01 to 214000 in the year 2004-05. The highest proportion of new IT labour outflow from colleges, expected to join the labour market in 2005-06, constitute those enrolled in the IT-professionals courses in degree and diploma colleges in the year 2004-05 (54\%) and the smallest proportion constitute those enrolled in the non-engineering fields $(20 \%)$. 
DSTI/DOC(2004)7

Table 8. Estimates of India's new IT labour supply, by educational institution (thousands)

\begin{tabular}{|l|r|r|r|r|r|}
\hline & $\mathbf{2 0 0 0 - 0 1}$ & $\mathbf{2 0 0 1 - 0 2}$ & $\mathbf{2 0 0 2 - 0 3}$ & $\mathbf{2 0 0 3 - 0 4}$ & $\mathbf{2 0 0 4 - 0 5}$ \\
\hline IT professionals from degree and diploma colleges & 74 & 91 & 100 & 110 & 116 \\
\hline Non-IT professionals from degree and diploma colleges & 32 & 36 & 38 & 43 & 56 \\
\hline IT labour from non-engineering fields & 27 & 32 & 35 & 38 & 43 \\
\hline Total new IT labour & $\mathbf{1 3 3}$ & $\mathbf{1 5 8}$ & $\mathbf{1 7 3}$ & $\mathbf{1 9 2}$ & $\mathbf{2 1 4}$ \\
\hline
\end{tabular}

Source: NASSCOM (2002).

In continuation, Table 9 covers data on IT labour supply in the Indian software sector. The table presents information relating to projections of out-migration and return-migration of IT professionals. The number of IT professionals leaving India (for on-site work) was 64000 in 2001-02, projected to decline to 21000 in the year 2004-05. This declining trend may be anticipated due to growth of software development within India during the coming years, particularly in cities like Bangalore, Hyderabad, Gurgaon and Noida (the last two near New Delhi). Software professionals are getting infrastructure and remuneration packages comparable to what they would get abroad. Furthermore, the recessionary conditions for IT in post 9/11 America have hit adversely the software sector in the developed world, which would discourage the out-migration of IT professionals in the times to come. The number of IT professionals returning to India is also projected to increase from 20000 in 2002-03 to 29000 in 2004-05.

It should be made clear that the estimated/projected stocks of India's new IT labour force are based on enrolment trends in IT-related courses as supplied by degree and diploma colleges (Table 8). However, the figures relating to new IT labour have been estimated on the basis of outflow, assuming zero wastage/drop-out.

Table 9. Net migration, cumulative stock and annual flow estimates of IT labour (software) supply in India (thousands)

\begin{tabular}{|l|r|r|r|r|r|}
\hline & $\mathbf{2 0 0 0 - 0 1}$ & $\mathbf{2 0 0 1 - 0 2}$ & $\mathbf{2 0 0 2 - 0 3}$ & $\mathbf{2 0 0 3 - 0 4}$ & $\mathbf{2 0 0 4 - 0 5}$ \\
\hline Existing stock (excluding ITES professionals) & & 360 & 429 & 542 & 675 \\
\hline India: New IT labour & & 133 & 158 & 173 & 192 \\
\hline -/- No. of IT professionals leaving India (onsite work) & & 64 & 64 & 64 & 21 \\
\hline No. of IT professionals returning to India & & - & 20 & 24 & 29 \\
\hline No. of IT professionals & $\mathbf{3 6 0}$ & $\mathbf{4 2 9}$ & $\mathbf{5 4 2}$ & $\mathbf{6 7 5}$ & $\mathbf{8 7 5}$ \\
\hline
\end{tabular}

Note: The above supply summary excludes ITES (IT enabled services) professionals.

Source: NASSCOM (2002).

\section{Doctors and nurses}

The number of doctors increased smoothly between 1991 and 2002, growing from 394000 to 585000 (see Figure 5). 
Figure 5. Number of doctors with recognised medical qualification (under the IMC Act) and registered with the State Medical Councils (thousands)

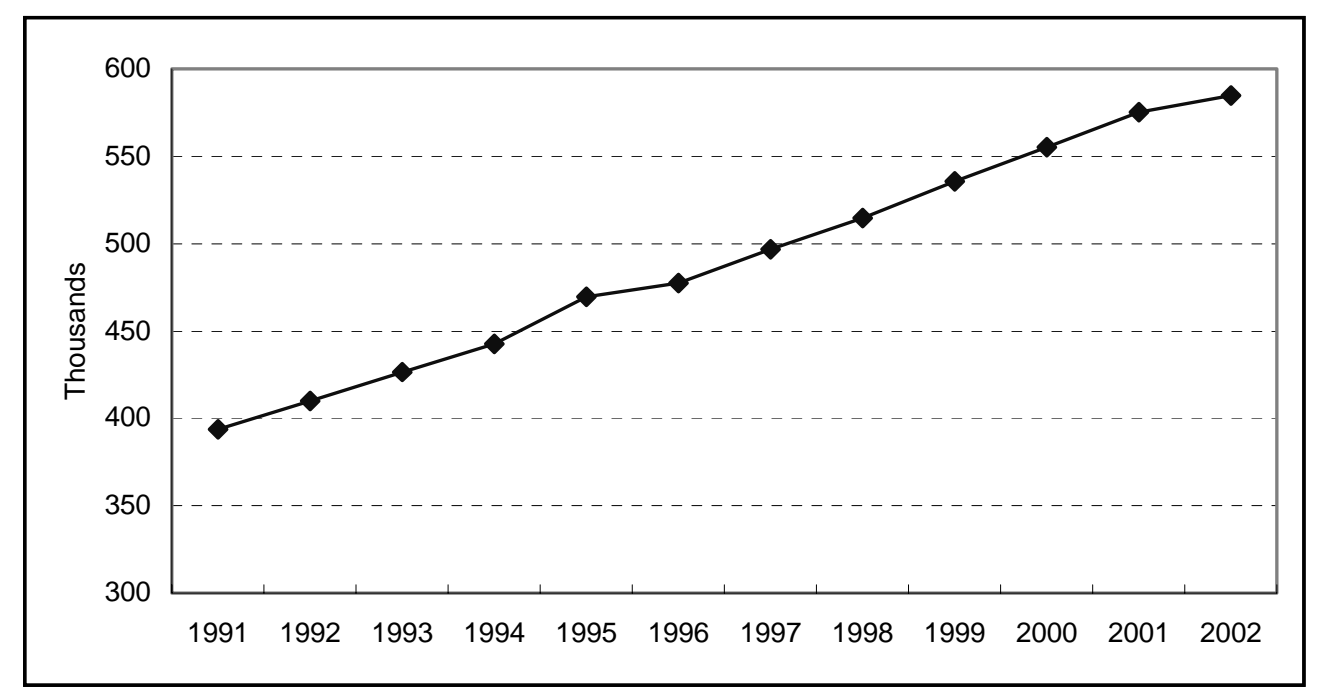

Source: Compiled from Medical Council of India, unpublished data.

Table 10 presents the flow of qualified nursing personnel registered in the State Nursing Registration Councils (SNRCs) of India. For this category, data is available only for two years, 1999 and 2000. It is an exhaustive table though, which incorporates data on different categories of nursing personnel by qualification, except for the highest possible category, i.e. M.Phil/PhD/Research where nobody had qualified, perhaps because no institutions offered these courses (except for an M.Phil course in only one institution under the Punjab and New Delhi Council).

The table gives a picture of eight categories of nursing personnel registered with various State Nursing Registration Councils in India, for the years 1999 and 2000. The total number of registrations has increased from 1.15 million in 1999 to 1.22 million in 2000. There was no registration of a single nurse having an M.Phil/PhD degree. Except for diploma holders in nursing education and administration (DNEA), all other categories of nursing personnel have registered an increase in 2000 over the previous year. The cause for the remarkably low figures under the DNEA category of nursing personnel is the reporting of data by only one state each year. The table further shows that there were about 411000 auxiliary nurse midwives in the health sector, while the total number of general nursing midwives stood at almost 776000 in 2000. The number of nurses having a Master's degree in nursing remained at a low of only 8 in 1999 and 2000 while nurses with a B.Sc. in nursing had increased from 792 to 831.

Table 10. Number of qualified nursing personnel registered in the State Nursing Registration Councils

\begin{tabular}{|l|r|r|}
\hline & $\mathbf{1 9 9 9}$ & $\mathbf{2 0 0 0}$ \\
\hline Auxiliary Nurse Midwives & 380593 & 411220 \\
\hline Health Visitors/Health Supervisors & 32249 & 35890 \\
\hline Diploma in Nursing Education and Administration (see note) & 239 & 108 \\
\hline General Nursing Midwives & 737280 & 775812 \\
\hline B.Sc. Nursing & 792 & 831 \\
\hline Post-Basic Bachelor of Science (Nursing) & 41 & 41 \\
\hline Master of Nursing & 8 & 8 \\
\hline Total & $\mathbf{1 1 5 1 2 0 2}$ & $\mathbf{1 2 2 3} \mathbf{9 1 0}$ \\
\hline
\end{tabular}

Note: Data for Diploma in Nursing Education and Administration in 1999 covers West Bengal only and in 2000 covers Haryana only. Source: Compiled from Indian Nursing Council, unpublished data. 


\section{Teachers}

Table 11 presents the stock of teachers by type of institution from 1981 to 1998 . It covers teachers in pre-primary schools and goes up to the universities and teachers working with 'Institutions of National Importance', like the Indian Institute of Technology, the Indian Institute of Management, the Indian Institute of Science Bangalore, etc. It also informs about the stock of teachers in professional institutions such as the Regional Engineering Colleges.

Table 11. Number of teachers in selected types of institution (thousands)

\begin{tabular}{|l|r|r|r|r|r|}
\hline & $\mathbf{1 9 8 1}$ & $\mathbf{1 9 9 1}$ & $\mathbf{1 9 9 6}$ & $\mathbf{1 9 9 7}$ & $\mathbf{1 9 9 8}$ \\
\hline Primary and secondary school & 3127 & 4024 & 4398 & 4528 & 4605 \\
\hline General Education graduate and above & 137 & 204 & 239 & 248 & - \\
\hline $\begin{array}{l}\text { University teaching department and other research } \\
\text { institutions of national importance }\end{array}$ & 27 & 59 & 71 & 73 & - \\
\hline
\end{tabular}

Sources: 1. Ministry of Human Resource Development: (i) Education in India; (ii) Selected Educational Statistics. 2. University Grants Commission.

Table 12 provides information on teachers in colleges and universities by their designation for the year 1999-2000. It shows that in the year 1999-2000, about 79000 teaching personnel were engaged in universities and university colleges (under the domain of universities), of which professors constituted $23 \%$, readers $28 \%$, senior lecturers $30 \%$, lecturers $17 \%$, and instructors only $2 \%$. The table further shows that about 272000 teachers were engaged in affiliated colleges in the same year, 1999-2000, of which 35\% were senior lecturers (including principals, professors, readers and persons with a lecturer grade), $63 \%$ lecturers and less than $2 \%$ tutors/instructors.

Table 12. Stock of teaching personnel in universities and affiliated colleges, 1999-2000 (numbers)

\begin{tabular}{|l|c|c|}
\hline & Universities and university colleges & Affiliated colleges \\
\hline Instructors & 1499 & 4349 \\
\hline Lecturers & 13205 & 172389 \\
\hline Senior Lecturers (see note) & 24013 & 95041 \\
\hline Readers & 22025 & \\
\hline Professors & 18143 & $\mathbf{2 7 1 7 7 9}$ \\
\hline Total & $\mathbf{7 8 ~ 8 8 5}$ & \\
\hline
\end{tabular}

Note: Data for senior lecturers in affiliated colleges are provisional, and include principals, professors, readers and selection grade lecturers.

Source: UGC, Annual Report 1999-2000. 


\section{International mobility of the highly skilled}

\subsection{Policy concerns in India on international migration of $\mathrm{HRST}^{2}$}

Today, India is almost at the top of the list of countries so far as emigration of the "brain drain" category of HRST is concerned, to developed countries like the United States, Canada, Australia, Germany, France, Japan and the United Kingdom. In the present Indian polity however, brain drain does not seem to be as much a cause of concern for the politicians or the bureaucracy as it used to be in the 1970s. In the early 1990s, the political perception of "brain drain" gradually gave way to the perception of "brain bank" abroad, a concept dear to the then Prime Minister Rajiv Gandhi. The emigration of Indian IT professionals is now being looked at as the complete reversal of the "brain drain", or a welcome fructifying of the "brain bank" into a "brain gain" through globalisation of the Indian talent and skills. Not merely economic, but political mileage that the Non-Resident Indians (NRIs) and Persons of Indian Origin (PIOs) can command for India in their countries of abode has also come to the centre-stage in recent years, particularly with liberalisation, globalisation and world competitiveness becoming the agenda of the nations - whether developed or developing.

The following statements from the present Prime Minister Atal Bihari Vajpayee's address to the Global Organization of Persons of Indian Origin (GOPIO) in New Delhi in January 2001, followed by the "Pravasi Bhartiya Divas" celebration on $9^{\text {th }}$ January 2003 reflect the perception of the Indian polity towards emigrants of India settled abroad, particularly the highly qualified and experienced. Expressing the pride of the Indian nation on the legendary success stories of Indian entrepreneurs abroad, he is reported to have said:

"From high-tech chip laboratories to curry restaurants, from renowned hospitals to famous educational institutions, from well-known research centres to leading think-tanks - everywhere you find an Indian who has overcome all odds to establish himself through skilled education and hard work."

He also said:

"Many of you owe your current success to the quality education which you have received in government-run institutions, be they Indian Institutions of Technology or medical colleges. You now owe it to your motherland to associate yourselves with India's search for rapid and enduring social change and economic progress";

and again:

"I would like to emphasize that we do not merely seek investments and asset transfer. What we seek is a broader relationship - in fact a partnership among all children of Mother India, so that our country can emerge as a major global player."

Finally, he said:

"My government's policy is to assist the overseas Indian community in maintaining its cultural identity and strengthening the emotional, cultural and spiritual bonds that bind them to the country of their origin."

2. Parts of this section have been drawn from Khadria (2002). See also Khadria (2003).

3. World Focus (2001). 
India has no well-defined immigration rules or law, whether for HRST or others. Provisions regarding entry, regulation and prevention of foreigners into India and Indian citizenship are found in the Constitution, the Citizenship Act 1955, the Foreigners Act 1946, the Passport Act 1967, the Criminal Procedure Code and other regulations. The other way around, there is an Emigration Act, 1983, which regulates emigration of workers from India to foreign countries, but these are meant for non-HRST categories of workers who are mostly unskilled and uneducated. Perhaps, this neglect of the highly skilled people has been because of the perception - as the Kothari Commission (GOI, 1966, section 198 on 'Brain drain') had observed - that "not all who go out of India are necessarily first-rate scientists, nor are they of critical importance to the country's requirements". What perhaps skipped the attention of the policy makers was the qualification that the Kothari Commission had added to its observation, saying: "but the problem is of sufficient importance to merit a close and systematic study" (GOI, 1966).

Policies that some developing countries have adopted from time to time to deal with brain drain, or the emigration of HRST, can be divided into four broad types: restrictive, compensatory, restorative and developmental. India has experimented with almost all of them at various points in time.

\section{Restrictive policies}

India generally does not have a restrictive policy for emigration of highly educated, trained and experienced personnel. From time to time various restrictive measures to contain the problem have been conceived, but there has never been a consensus except in the case of the medical sector - where India has certain restrictions. ${ }^{4}$ But these also originated as India's quid pro quo response to the highly restrictive US regulations for entry of medical personnel into the US geo-economic sphere. The Indian policy is expected to regulate the flow of doctors and is influenced by highly subsidised education provided to them. This however is effective in taking care of only the emigrating doctors and medical students, who comprise only $15 \%$ of the total student outflow from the country. Nearly $40 \%$ of the students go abroad for engineering and technology, $25 \%$ for management, and $20 \%$ for other subjects. However, it is not the medical education only, not even professional education only, but the entire tertiary sector of education which is subsidised in India. ${ }^{5}$ Therefore, restrictive policy, if it has to be effectively implemented, should be devised for the higher education sector as a whole.

\section{Compensatory policies}

There is no formal compensatory mechanism to compensate for the losses that India incurs because of migration. There is a policy in terms of incentives offered to the NRIs for sending funds to India through the official channels - remittances, investments in bank deposits, occasionally floated development bonds, securities of Indian companies, joint ventures and so on. Most of the incentives are in the form of higher rates of interest and lower rates of taxes for the NRIs as compared to their counterpart residents in India. In fact, the term 'non-resident' was coined for the purpose of extending tax concessions to temporary visitors abroad, so that they were not subjected to double taxation - once in the host country and again in India. Most of these schemes have attracted financial transfers to India, but have faced the scrutiny of efficacy in terms of going into conspicuous consumption or what Krueger and Bhagwati would call "Directly Unproductive Profit-making (DUP) activities". 6 One can also mention the well-known Bhagwati-proposal

4. There is a history of three decades of restrictive policies for medical education abroad. It started initially with the objective of controlling foreign exchange outflow and optimum use of facilities in India. Later the rationale was to regulate the out-migration of doctors and derive the benefits of highly subsidised medical education provided to them for the country's poor.

5. See Khadria (1989) for the rationale behind these subsidies in India at the post-compulsory level of education.

6. See Krueger (1974) and Bhagwati (1982). 
of 1976, which proposed to tax the brain drain for creating a development fund that would benefit the developing countries losing their skilled labour to the developed world. ${ }^{7}$ However, it could not be tested due to problems of multilateral jurisdiction across countries.

\section{Restorative policies}

Restorative policies are aimed at encouraging return migration to India, either permanently or temporarily on specific assignments. The best known schemes under this category have been the Pool Officers Scheme for permanent returnees launched by the Council for Scientific and Industrial Research (CSIR) of the Government of India, and the TOKTEN-INRIST ${ }^{8}$ scheme for temporarily returning scientists launched by CSIR in collaboration with the UNDP. ${ }^{9}$ Both schemes have been quite ineffective - due to poor offers and poor implementation respectively. Private initiative was only through the TOKTEN-INRIST, where private industrial establishments were encouraged to offer placements to the returning/visiting NRIs in their R\&D units. The private firms were, however, frustrated and disillusioned with the bureaucratic style of functioning of the CSIR as it implemented the TOKTEN programme in India. ${ }^{10}$

The University Grants Commission started a scheme to attract Indian scientists abroad with offers of placement in Indian universities at levels parallel to lecturer, reader and professor in the early 1980s, with substantial research grants in addition to their salaries. The scheme took-off well, but ran into trouble because of the dilution of standards by accommodating unemployed scholars from within India in all disciplines. It also led to dichotomies in the universities, where the research scientists were treated as 'second-class citizens' by the permanent faculty. To get over this, the UGC turned the appointments, initially made for five year renewable tenures, into permanent appointments. However, subsequent groups were not treated the same, first of all because their appointments were temporary and non-renewable after the first tenure of five years. In addition, in the original scheme, there were provisions for promotion from one level to another after every five years, subject to evaluation of progress of work, which was not offered to later entrants in the scheme. The UGC finally ran into budget trouble, and the scheme was withdrawn some time in the mid-nineties for fresh appointments, when phasing out of the old non-renewable positions started as well.

Recently, the Government of India has, through official notification, introduced what is called the PIO-Card for persons of Indian origin who have obtained foreign citizenship by surrendering their Indian citizenship. ${ }^{11}$ The PIO scheme was announced by the Ministry of Home Affairs in the Gazette of India dated 30 March 1999. ${ }^{12}$ With the exception of those who now hold citizenship of Pakistan, Bangladesh and other countries that may be specified from time to time, the scheme is directed at any holders of Indian passports in the past; the children, grandchildren, and great-grandchildren of those who were born in India and were permanently resident in India as defined in the Government of India Act, 1935 and other

7. Bhagwati and Partington (1976).

8. Transfer of Knowledge and Technology through Expatriate Nationals - Interface for Non-Resident Indian Scientists \& Technologists (TOKTEN-INRIST).

9. UNDP has sponsored the TOKTEN programme in many developing countries experiencing brain drain.

10. See Khadria (1999a), Chapter 6.

11. Indian citizens are not eligible for dual citizenship except for those living in 16 selected countries who are now offered the option of dual citizenship as a follow up to the announcement made on the Second Indian Expatriates Day on 9 January 2004.

12. The Gazette of India, Regd. No.D.L.33004/98, Extraordinary, No. 63: PIO Card Scheme, New Delhi, March 30, 1999. 
territories that became part of India thereafter; and spouses of citizens of India or PIOs as per the criteria of the PIO Card scheme. All these people are entitled to apply and get the PIO Card, which has a validity of 20 years, along with a passport, by paying a fee of USD 1000 (inclusive of a non-refundable processing fee of USD 250). The card allows a waiver on visas for entering India; exemption from the requirement of registration for stays up to 180 days; and parity with NRIs in respect of all facilities available to the latter in the economic, financial and educational field, except for acquisition of agricultural/plantation properties. The card does not give any political rights.

The PIO Card scheme was designed to strengthen the link of the expatriates of Indian descent, including Indian-born naturalised American citizens, with India. A large number of PIOs had, in fact, been asking for dual citizenship from India so that they could keep their contacts with the home country with ease. The PIO Card was the second-best offer the Indian Government could provide, because the proposal for dual citizenship was not acceptable for reasons of national security, and other possible abuses by anti-national and anti-social elements. The PIO Card scheme however failed to evoke an enthusiastic response. ${ }^{13}$ With the recent celebration of the "Overseas Indians Day" (the Pravasi Bharatiya Divas) on 9 January 2003 and 2004, the announcement of granting dual citizenship by India to Persons of Indian Origin in selected countries, mainly the west, was finally made, but it is too early to comment on the outcome of this new policy instrument.

\section{Developmental policies}

Developmental policies are not specifically aimed at brain drain per se, but supposedly at the causes of brain drain in terms of bridging the development gap between the developing sending country and the developed receiving country. So far, these have remained promises only, either in writing or through public statements, lacking in direction and being very ad hoc. These policies work more as attention-drawing promises made by political parties in their election manifestos, with no follow up whatsoever, if the party came to power. ${ }^{14}$ Examples are the proposal for the setting up of science parks where wages will be comparable to international standards and working conditions will not be repressive, Export Processing Zones (EPZs) where tariff barriers will not exist for undertaking certain production activities, and so on.

Currently, the kind of policy India is more concerned with in respect of migration of HRST may be summarised in terms of the recent pronouncements by the Prime Minister at the $90^{\text {th }}$ Indian Science Congress in Bangalore (Hindustan Times, Jan. 4, 2003). The four steps he suggested are the following.

On red tape:

"We have to ensure that our scientific institutions do not become afflicted with the culture of our governmental agencies."

On internal brain drain:

"Closely linked to the bureaucratic culture is the disturbing trend of internal brain drain... from $\mathrm{R} \& \mathrm{D}$ careers to non-scientific careers in the government and private sector. We need to examine why a career in science is not considered worthwhile by so many of our talented younger scientists."

13. Only about 1100 PIOs applied for the Card in one and a half year.

14. Of late, however, the Indian judiciary has begun taking the government to task for non-performance on promises made, e.g. in the case of the universal primary education until the age of 14 (see Majumdar, 1998). 
DSTI/DOC(2004)7

On external brain drain:

"Another related issue is the need, and the opportunity, to attract our large and accomplished scientific diaspora. We should devise pragmatic and flexible schemes to enable them to work in our institutions."

On education:

"I wish to briefly touch upon a disturbing trend. While we have several exceptional scientific and technological institutions, some others turn out graduates and post-graduates, even doctorates of indifferent quality. We need to reflect on this and take corrective action."

These indicate the tendencies that Indian policies may reflect, in the future, on return migration, temporary migration, circulatory migration and so on.

\subsection{International migration data}

An essential pre-requisite for working towards implementing the policy tendencies mentioned above is the availability of systematic and organised data on international migration of HRST from and to India. India does not have any systematic data collection or complete data set on in-migration from abroad, whether for HRST or otherwise. Concerning in-migration of HRST, some data are available for tertiary-level students (considered part of life-time HRST stocks and flows by the Canberra Manual, because they are eligible to enter the high-skill labour market on the basis of education already acquired at the preceding level of study programmes) coming to India under various government-sponsored schemes. The same is the case for out-migration of students from India. These data are presented, but otherwise, emigration records for HRST are generally scanty and patchy in India.

Concerning the emigration of Indian HRST to other countries, Indian sources thus offer no help except for some institution-based sample surveys of brain drain, such as from a few IITs, the All India Institute of Medical Sciences (AIIMS), and the Banaras Hindu University. Since immigration statistics in developed receiving (host) countries are usually more comprehensive and more reliable than emigration statistics from India, this section looks at HRST immigration statistics of the "main receiving country for Indian HRST', which is the United States, and presents tables from some of the US sources, e.g. on PhD awardees" "plans to stay" and "firm plans to stay" in the United States for postdoctoral research.

It was not possible to include the immigration statistics from host country sources other than a few American sources. Apart from the fact that most of these are not easily accessible from India, some that are available do not provide an adequate breakdown for India as a separate country. Indian statistics are merged into 'Asian' or 'South Asian' statistics in these sources, making them less useful for the purpose. Having noted this, a selection of tables containing various types of mobility data on Indian HRST is presented below.

Table 13 provides the immigration of international students, who have been admitted to Indian universities and institutes of higher learning for pursuing higher education between 1990-1991 and 1999-2000 by region of origin. It has to be mentioned here that because of the non-availability of data from some Indian universities regarding the number of foreign students admitted into those universities, the figures given in the table may be a little lower than the real numbers. It is evident from the table that Africa and Asia have sent greater numbers of students to Indian universities, while the presence of students from American and European regions in Indian universities/institutions of higher learning has been quite low. A close analysis of the table shows that the inflow of foreign students in India has been fluctuating throughout the period for which data are shown. The 'total' indicates that up to 1993-94, the inflow has gone up, but in the years to follow it has come down substantially. In the academic year 1998-99 the lowest 
number of foreign students, i.e. slightly over 5000 , are reported to have been admitted in Indian universities.

Table 13. Number of foreign students in Indian universities

\begin{tabular}{|l|r|r|r|r|r|r|r|r|r|}
\hline Region & $\mathbf{9 0 - 9 1}$ & $\mathbf{9 2 - 9 3}$ & $\mathbf{9 3 - 9 4}$ & $\mathbf{9 4 - 9 5}$ & $\mathbf{9 5 - 9 6}$ & $\mathbf{9 6 - 9 7}$ & $\mathbf{9 7 - 9 8}$ & $\mathbf{9 8 - 9 9}$ & $\mathbf{9 9 - 0 0}$ \\
\hline Asia & 5776 & 5111 & 5898 & 5060 & 4871 & 2 763 & 3640 & 2765 & 3523 \\
\hline Africa & 6318 & 7084 & 7109 & 5852 & 4081 & 2680 & 2536 & 2085 & 2558 \\
\hline Europe & 173 & 153 & 187 & 120 & 127 & 91 & 151 & 111 & 120 \\
\hline North America & 234 & 134 & 247 & 418 & 299 & 161 & 132 & 117 & 270 \\
\hline Central \& Sth. America & 29 & 17 & 13 & 8 & 10 & 2 & 8 & 7 & 5 \\
\hline Miscellaneous & 369 & 326 & 253 & 430 & 699 & 144 & 234 & 238 & 512 \\
\hline Total & $\mathbf{1 2 ~ 8 9 9}$ & $\mathbf{1 2 ~ 8 2 5}$ & $\mathbf{1 3 7 0 7}$ & $\mathbf{1 1 8 8 8}$ & $\mathbf{1 0 ~ 0 8 7}$ & $\mathbf{5 8 4 1}$ & $\mathbf{6 ~ 7 0 1}$ & $\mathbf{5 3 2 3}$ & $\mathbf{6 9 8 8}$ \\
\hline
\end{tabular}

Note: The figures could be somewhat higher as a few universities have not submitted information.

Source: Selected statistical data on Indian higher education-iv; International education cell, Student information services division; Association of Indian Universities, New Delhi. p.12.

Table 14 provides the distribution of Indian students who have gone abroad for higher studies under various government schemes during the period from 1991-92 to 1997-98. The table shows that the outflow of students from the academic fields of 'engineering and architecture', 'science' and 'agriculture and forestry' have declined substantially, while the outflow of students studying 'commerce and business', 'arts', 'fine arts', 'law' and 'medicine' has increased over the years. During the mid-90s, the out-migration of Indian students for higher studies went up very sharply. It reached its lowest level during 1993-94, but in the following years it increased at an exceptionally high rate throughout the period for which data are shown in the table.

Table 14. Number of students going abroad under various government schemes for higher studies, by field of study

\begin{tabular}{|c|c|c|c|c|c|c|c|c|}
\hline & $1991-92$ & $1992-93$ & 1993-94 & 1994-95 & $1995-96$ & $1996-97$ & $1997-98$ & $\%$ fem. \\
\hline Engineering and architecture & 2390 & 2460 & 709 & 792 & 703 & 1473 & 1014 & 9.5 \\
\hline Science & 1384 & 1447 & 575 & 340 & 387 & 631 & 789 & 16.2 \\
\hline Technology and industry & 121 & 115 & 43 & 141 & 98 & 381 & 325 & 10.8 \\
\hline Commerce and business & 946 & 795 & 341 & 646 & 957 & 1777 & 2592 & 11.3 \\
\hline Arts & 204 & 191 & 130 & 111 & 177 & 235 & 302 & 42.1 \\
\hline Agriculture and forestry & 94 & 66 & 12 & 16 & 15 & 80 & 11 & 54.5 \\
\hline $\begin{array}{l}\text { Medicine, pharmacy and } \\
\text { veterinary science }\end{array}$ & 350 & 449 & 85 & 327 & 370 & 907 & 607 & 16.8 \\
\hline Law & 26 & 21 & 9 & 18 & 23 & 43 & 55 & 29.1 \\
\hline Banking/Banking institutions & 14 & 6 & 9 & 2 & 25 & 38 & 15 & 6.7 \\
\hline Fine arts & 30 & 69 & 0 & 42 & 39 & 69 & 62 & 46.8 \\
\hline Others & 905 & 880 & 371 & 548 & 684 & 792 & 962 & 23.8 \\
\hline Total & 6466 & 6499 & 2284 & 2983 & 3478 & 6426 & 6734 & 15.8 \\
\hline
\end{tabular}

Source: Ministry of Human Resource Development, Indian Students/Trainees Going Abroad, cited in Manpower Profile 2001.

Table 15 is an extension of Table 14, providing the distribution of Indian students and trainees who have gone abroad for higher studies under various government schemes, by field of study and continent. These data are presented only for two consecutive years, 1996-97 and 1997-98. The table shows that America has been the most favoured destination for Indian students for higher studies, followed by Oceania (Australia and New Zealand) and Europe. Students from all academic fields have gone to these continents. As a destination for out-migration of Indian students, Asian countries could not attract comparable numbers of students from India. 


\section{DSTI/DOC(2004)7}

The highest number of students went abroad for higher studies in the academic fields of 'commerce, business administration and management' followed by 'engineering and architecture' and 'medicine'. These figures may be indicative of the government's inclination towards promoting quality and excellence in the emerging areas of science and technology, commerce, medicine and management.

Table 15. Indian students going abroad on government schemes, broken down by continent (\%)

\begin{tabular}{|l|rr|rr|rr|rr|r|r|}
\hline & \multicolumn{2}{|c|}{ America } & \multicolumn{2}{|c|}{ Europe } & \multicolumn{2}{c|}{ Asia } & \multicolumn{3}{c|}{ Oceania } & \multicolumn{2}{c|}{ Others } \\
\hline & $\mathbf{9 6 - 9 7}$ & $\mathbf{9 7 - 9 8}$ & $\mathbf{9 6 - 9 7}$ & $\mathbf{9 7 - 9 8}$ & $\mathbf{9 6 - 9 7}$ & $\mathbf{9 7 - 9 8}$ & $\mathbf{9 6 - 9 7}$ & $\mathbf{9 7 - 9 8}$ & $\mathbf{9 6 - 9 7}$ & $\mathbf{9 7 - 9 8}$ \\
\hline Engineering \& architecture & 69.9 & 63.8 & 18.3 & 17.2 & 0.3 & 2.0 & 10.7 & 15.1 & 1.0 & 2.0 \\
\hline Science & 64.5 & 59.7 & 12.7 & 17.9 & 0.3 & 0.8 & 21.6 & 18.8 & 1.0 & 2.9 \\
\hline Technology \& industry & 42.5 & 23.7 & 13.9 & 11.7 & 1.0 & 0.6 & 38.8 & 63.1 & 3.7 & 0.9 \\
\hline $\begin{array}{l}\text { Commerce, business admin. } \\
\text { \& management }\end{array}$ & 31.3 & 21.6 & 18.2 & 16.7 & 3.2 & 3.1 & 44.6 & 57.6 & 2.8 & 1.0 \\
\hline Arts & 57.9 & 50.3 & 21.3 & 31.8 & 1.7 & 2.0 & 18.3 & 13.6 & 0.9 & 2.3 \\
\hline Agriculture \& forestry & 28.8 & 45.5 & 51.3 & 27.3 & 0.0 & 0.0 & 18.8 & 27.3 & 1.3 & 0.0 \\
\hline $\begin{array}{l}\text { Medicine, pharmacy, dentistry } \\
\text { \& veterinary sciences }\end{array}$ & 36.8 & 7.4 & 46.9 & 82.7 & 0.4 & 1.2 & 10.5 & 7.4 & 5.4 & 1.3 \\
\hline Law & 18.6 & 25.5 & 74.4 & 70.9 & 0.0 & 0.0 & 4.7 & 3.6 & 2.3 & 0.0 \\
\hline Banking services & 39.5 & 26.7 & 42.1 & 13.3 & 0.0 & 0.0 & 18.4 & 60.0 & 0.0 & 0.0 \\
\hline Fine arts & 68.1 & 72.6 & 15.9 & 22.6 & 0.0 & 0.0 & 15.9 & 4.8 & 0.0 & 0.0 \\
\hline Others & 38.5 & 41.7 & 14.9 & 20.4 & 1.3 & 2.6 & 38.9 & 32.6 & 6.4 & 2.7 \\
\hline Total & 47.0 & 36.0 & 22.1 & 24.3 & 1.3 & 2.2 & 26.7 & 35.9 & 2.9 & 1.7 \\
\hline
\end{tabular}

Source: Compiled by the author from Government of India, Ministry of Human Resource Development, Indian Students and Trainees Going Abroad, New Delhi.

The data in Table 15 are only shown in the form of percentages, since the data are limited to the number of those who have gone abroad under government schemes. Hence it provides only a partial picture of the presence of India's "semi-finished" HRST in the world market of human capital. The next three figures give a more complete picture of the out-migration of Indian students.

Figure 6 presents data from OECD's education database, showing the number of foreign students (using the left-hand axis) and the number of Indian students (using the right-hand axis) enrolled in higher education studies in OECD countries from 1998 to 2001. In both cases, the numbers have been rising. The number of foreign students enrolled in tertiary education in OECD countries increased from 1.3 million to 1.5 million in those four years, of which the number of Indians went up from 40000 to 61000. 
Figure 6. Foreign students enrolled in tertiary education in OECD countries (thousands)

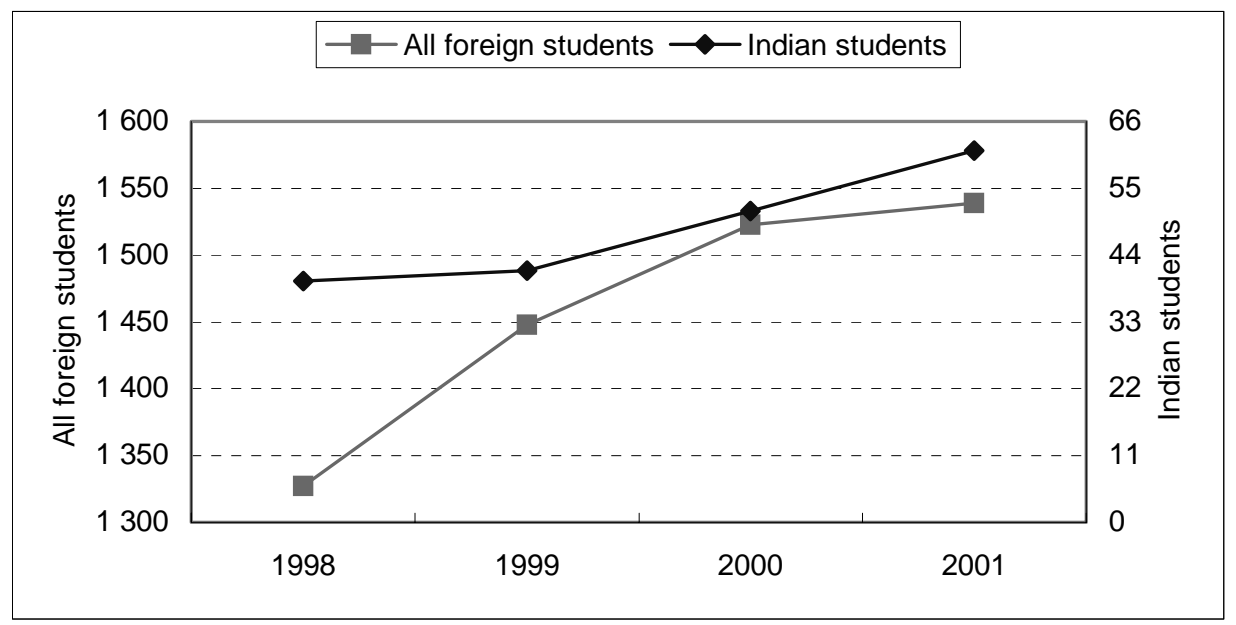

Note: Data for 1998 exclude Belgium, Greece, Mexico, the Netherlands, Portugal and the Slovak Republic; data for 1999 excluding Greece and Portugal; data for 2000 exclude Greece and Luxembourg; data for 2001 exclude Canada, Greece, Luxembourg and Portugal.

Source: OECD Education database.

Clearly, the Unites States is the most favoured destination, attracting 47000 Indian students in 2001, accounting for $78 \%$ of all Indian students enrolled in OECD countries (see Figure 7).

Figure 7. Distribution of Indian students in tertiary education over receiving OECD countries, 2001

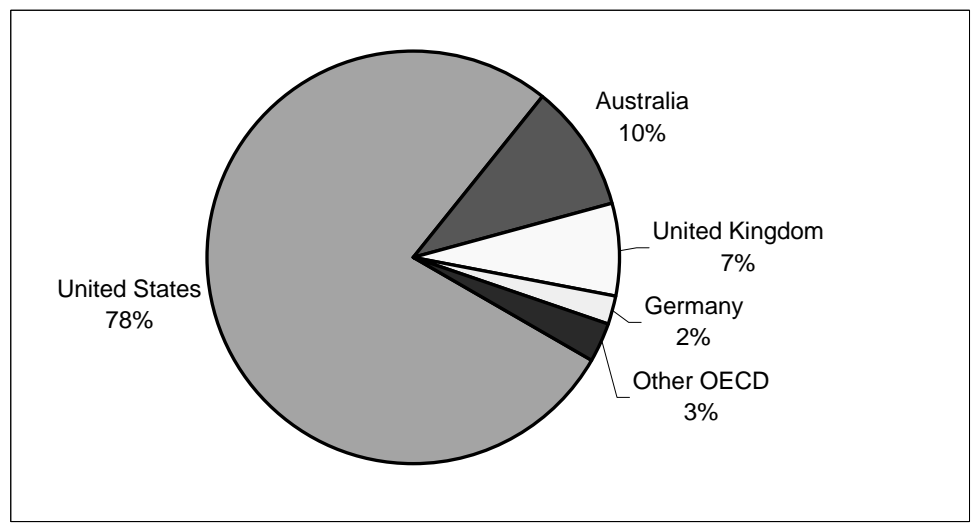

Note: Excluding data for Canada, Greece, Luxembourg and Portugal.

Source: OECD Education database.

Figure 8 shows that Indian students accounted for $4 \%$ of all foreign students enrolled in tertiary education in OECD countries in 2001. A far larger share was registered for the United States, where 10\% of enrolled foreign students were Indian. 
Figure 8. Indian students as a percentage of all foreign students in receiving country, 2001

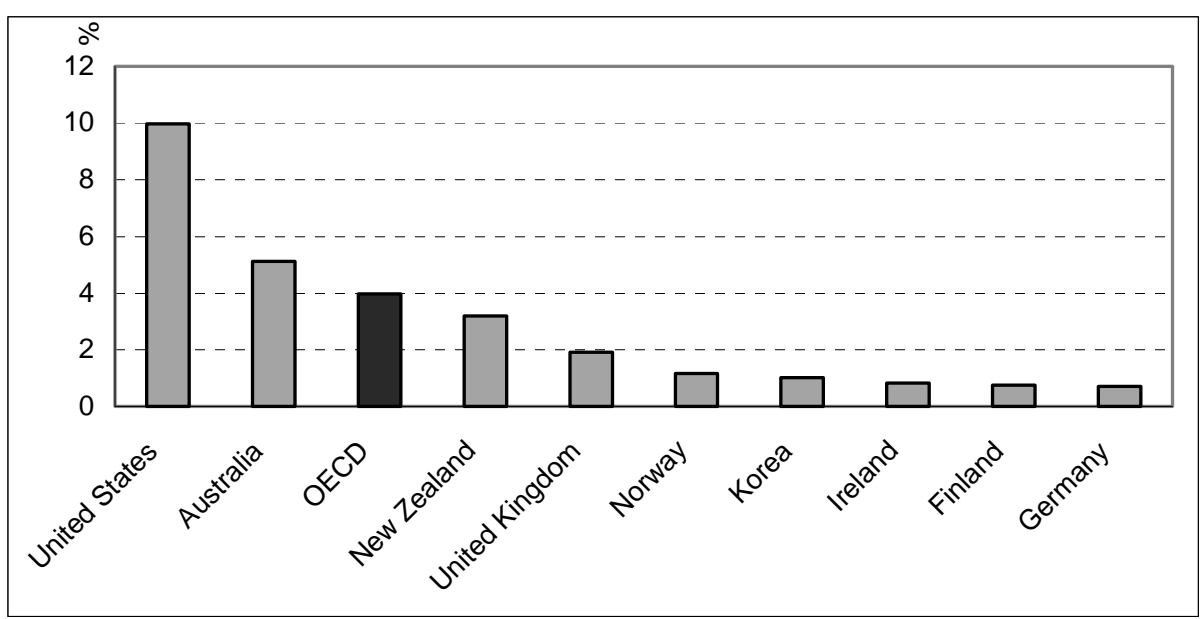

Note: Excluding data for Canada, Greece, Luxembourg and Portugal.

Source: OECD Education database.

Table 16 contains the flow data of Indian students who have gone to the United States particularly for higher studies between 1970 and 2001. Even a cursory look on the table is sufficient to convey that there have been massive fluctuations in the outflow of Indian students to the United States.

Table 16. Indian students entering the United States, 1970-2001

\begin{tabular}{|l|c|c|}
\hline & Number of students & Average for one year \\
\hline $1970-74$ & 24126 & 4825 \\
\hline $1975-79$ & 14385 & 2877 \\
\hline $1980-81$ &.. &.. \\
\hline $1982-84$ & 16699 & 5566 \\
\hline $1985-89$ & 54804 & 10961 \\
\hline $1990-91$ & 29648 & 14824 \\
\hline $1992-93$ & 27791 & 13875 \\
\hline $1994-96$ & 48399 & 16133 \\
\hline 1997 &.. &.. \\
\hline 1998 & 25543 & 25543 \\
\hline 1999 & 28335 & 28335 \\
\hline 2000 & 39795 & 39795 \\
\hline 2001 & 48809 & 48809 \\
\hline
\end{tabular}

Source: INS, Statistical Yearbook; data until 1996 cited in Khadria (1999a).

Table 17 contains the distribution of Indians who received their doctorates from US universities by major field of study and their intention to stay in the United States after completing their education. It is evident from the table that more than 50\% of the total has "firm plans to stay" (i.e. they have confirmed offers of postdoctoral appointments). A close analysis of the table also shows that a comparatively lower number of doctoral recipients from social sciences have "plans to stay" (i.e. intentions to stay, possibly supported by applications, but without confirmed offers of postdoctoral placements yet) in the United States. Analysis by year shows that the proportion of Indian doctoral recipients in all fields, who plan to stay in the United States, as well as those who have firm plans to stay, generally increased after 1990. 
DSTI/DOC(2004)7

Table 17. Indian doctoral recipients from US universities, with plans to stay in the United States, 1991-99

\begin{tabular}{|l|r|r|r|r|r|r|r|r|r|}
\hline & $\mathbf{1 9 9 1}$ & $\mathbf{1 9 9 2}$ & $\mathbf{1 9 9 3}$ & $\mathbf{1 9 9 4}$ & $\mathbf{1 9 9 5}$ & $\mathbf{1 9 9 6}$ & $\mathbf{1 9 9 7}$ & $\mathbf{1 9 9 8}$ & $\mathbf{1 9 9 9}$ \\
\hline All fields & & & & & & & & & \\
\hline No. of PhDs & 924 & 1072 & 1139 & 1289 & 1425 & 1500 & 1427 & 1285 & 1077 \\
\hline \% plan to stay & 74.6 & 82.1 & 80.8 & 81.4 & 82.7 & 84.3 & 80.7 & 85.3 & 88.9 \\
\hline \% firm plan to stay & 56.1 & 56.8 & 50.7 & 51.4 & 52.4 & 58.8 & 59.4 & 65.5 & 64.8 \\
\hline All sciences \& engineering & & & & & & & & & \\
\hline No. of PhDs & 752 & 860 & 932 & 1065 & 1206 & 1276 & 1211 & 1082 & 888 \\
\hline \% plan to stay & 73.7 & 81.7 & 81.4 & 81.8 & 83.2 & 85.0 & 81.5 & 86.8 & 89.6 \\
\hline \% firm plan to stay & 54.3 & 56.4 & 49.6 & 50.3 & 52.4 & 59.0 & 59.5 & 67.8 & 64.6 \\
\hline Natural sciences & & & & & & & & & \\
\hline No. of PhDs & 304 & 365 & 382 & 474 & 499 & 520 & 515 & 471 & 406 \\
\hline \% plan to stay & 74.0 & 84.1 & 82.5 & 82.1 & 83.6 & 87.3 & 81.0 & 87.5 & 90.6 \\
\hline \% firm plan to stay & 57.2 & 60.3 & 52.4 & 53.0 & 56.3 & 60.8 & 57.3 & 67.3 & 63.8 \\
\hline Engineering & & & & & & & & & \\
\hline No. of PhDs & 357 & 405 & 448 & 480 & 572 & 625 & 587 & 518 & 368 \\
\hline \% plan to stay & 76.2 & 82.7 & 82.1 & 83.8 & 85.5 & 86.2 & 83.8 & 88.2 & 90.8 \\
\hline \% firm plan to stay & 53.5 & 54.8 & 46.7 & 49.0 & 51.0 & 60.2 & 63.5 & 71.2 & 67.1 \\
\hline Social sciences & & & & & & & & & \\
\hline No. of PhDs & 91 & 90 & 102 & 111 & 135 & 131 & 109 & 93 & 114 \\
\hline \% plan to stay & 62.6 & 67.8 & 74.5 & 72.1 & 71.9 & 69.5 & 71.6 & 75.3 & 82.5 \\
\hline \% firm plan to stay & 47.3 & 47.8 & 52.0 & 45.0 & 43.7 & 46.6 & 47.7 & 51.6 & 59.6 \\
\hline
\end{tabular}

Notes: Foreign doctoral recipients are on temporary visas. Natural sciences include physical, earth, atmospheric, oceanographic and biological sciences. Social sciences include psychology, sociology and other social sciences. Those who 'plan to stay' think that they will locate in the United States. Those with 'firm plans to stay' have a post-doctoral research appointment, or academic, industrial, or other firm offer of employment in the United States.

Source: National Science Foundation, United States, Science and Engineering Indicators 2002.

Table 18 provides the percentage shares of Indian doctoral recipients in 1992-93 in US universities in science and engineering, who have been working in the United States in the years 1994, 1995, 1996 and 1997. The data show that a comparatively larger percentage of Indian doctoral recipients in engineering and a comparatively lower percentage in the social sciences have been returning to the United States as immigrants (permanent-stay visas) after completing their temporary student visa stays. It is noticeable that the percentage of Indian doctoral recipients returning to the United States, after the 'mandatory two-year stay' outside the United States (which is the reason why the numbers are increasing as the years go by), has increased consistently over the years for all disciplines, except for the life sciences, which shows a fall between 1996 and 1997, thereby indicating a net emigration from the United States. 
Table 18. Indian recipients of doctoral degrees in science and engineering in 1992-93 from US universities, working in the United States, 1994-97

\begin{tabular}{|l|r|r|r|r|r|}
\hline & $\begin{array}{c}\text { All sciences \& } \\
\text { engineering }\end{array}$ & $\begin{array}{c}\text { Physical } \\
\text { sciences }\end{array}$ & $\begin{array}{c}\text { Life } \\
\text { sciences }\end{array}$ & Engineering & $\begin{array}{c}\text { Social } \\
\text { sciences }\end{array}$ \\
\hline $\begin{array}{l}\text { Number of Indian PhD recipients } \\
\text { in the Unites States in 1992-93 }\end{array}$ & 1549 & 423 & 237 & 740 & 149 \\
\hline$\%$ in the United States in 1994 & 77 & 72 & 70 & 85 & 56 \\
\hline$\%$ in the United States in 1995 & 80 & 77 & 75 & 89 & 56 \\
\hline$\%$ in the United States in 1996 & 82 & 80 & 82 & 89 & 58 \\
\hline$\%$ in the United States in 1997 & 83 & 81 & 79 & 90 & 58 \\
\hline
\end{tabular}

Notes: Foreign doctoral recipients are on temporary visas. Physical sciences include earth, atmospheric, and oceanographic sciences, mathematics, and computer sciences. Social sciences include psychology, sociology, and other social sciences.

Source: National Science Foundation, United States, Science and Engineering Indicators 2000.

In 1999, there were 165000 Indian residents in the United States with a science and engineering highest degree. They accounted for $13 \%$ of the total number of foreign-born US residents with S\&E highest degrees, which was more than any other country (see Figure 9).

Figure 9. Foreign-born US residents with S\&E highest degrees by place of birth, 1999

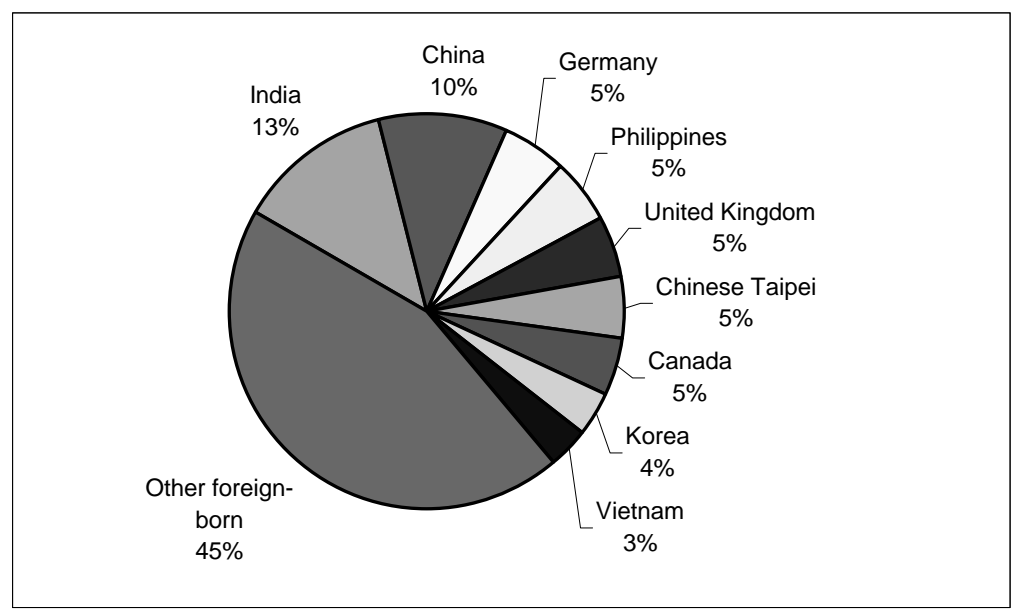

Note: Data exclude individuals with foreign degrees only, who were not in the United States in 1990.

Source: National Science Foundation, Division of Science Resources Statistics (NSF/SRS), Scientists and Engineers Statistical Data System (SESTAT), 1999.

India also accounted for a high share of foreign-born residents, with a science and engineering doctorate, residing in the United States in $1999,16 \%$ or 30000 people, second only to China, as is shown in Figure 10. 
DSTI/DOC(2004)7

Figure 10. Number of foreign-born US residents with S\&E doctorates by place of birth, 1999

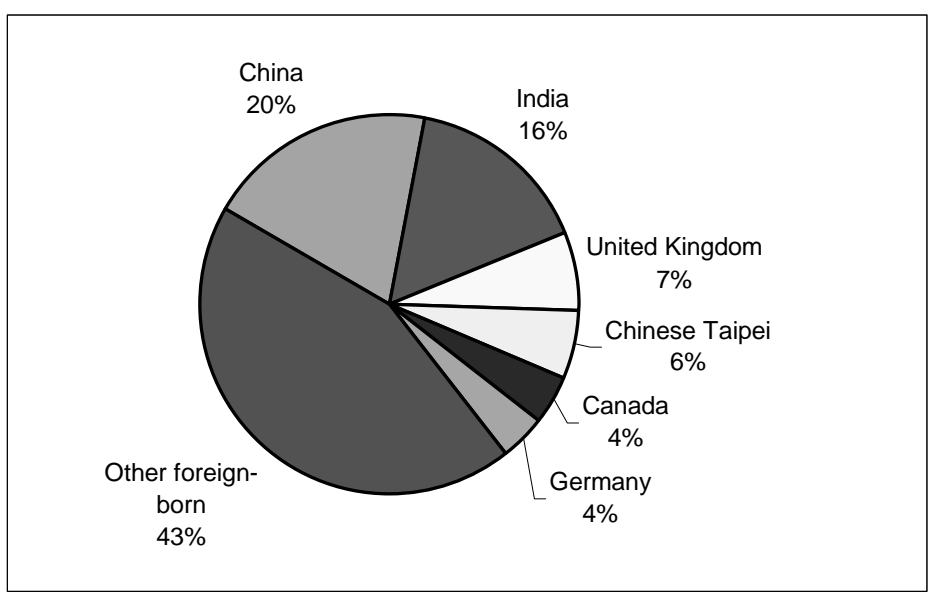

Note: Data exclude individuals with foreign degrees only, who were not in the United States in 1990.

Source: National Science Foundation, Division of Science Resources Statistics (NSF/SRS), Scientists and Engineers Statistical Data System (SESTAT), 1999.

Table 19 gives a very comprehensive overview of Indians amongst the science and engineering faculties in US higher education by teaching field in a comparative perspective. The table shows that amongst the American science and engineering faculties, almost 7000 teaching staff are of Indian origin, constituting $3 \%$ of the total faculty strength, and were $15 \%$ of the total faculty of foreign origin in science and engineering in 1997. The largest chunk of Indians is concentrated in engineering, followed by mathematics and computer sciences, where they constitute almost $7 \%$ and $5 \%$ respectively of the total teaching faculty. In contrast, their representation is quite low in physical and life science faculties.

Table 19. Indians amongst teaching staff at science and engineering faculties in the United States by teaching field, 1997

\begin{tabular}{|l|c|r|r|r|r|}
\hline & $\begin{array}{c}\text { Total science \& } \\
\text { engineering }\end{array}$ & Indian origin & $\%$ of total & \% of foreign & $\begin{array}{r}\text { Female \% of } \\
\text { Indian persons }\end{array}$ \\
\hline Total S\&E & 224707 & 6876 & 3.1 & 15.3 & 12.1 \\
\hline Physical sciences & 37020 & 688 & 1.9 & 9.3 & 16.7 \\
\hline Life sciences & 53055 & 1014 & 1.9 & 13.4 & 31.6 \\
\hline Math. \& computer sciences & 44375 & 2086 & 4.7 & 18.3 & 13.9 \\
\hline Social sciences & 65509 & 1491 & 2.3 & 15.5 & 6.3 \\
\hline Engineering & 24748 & 1597 & 6.5 & 17.8 & 0.9 \\
\hline
\end{tabular}

Note: Data include first jobs of post-secondary teaching at four-year colleges and universities in the United States, but exclude faculties in two-year or community colleges, or those who teach as a secondary job.

Source: Computed and compiled from National Science Foundation, United States, Science and Engineering Indicators 2000.

Table 20 contains the occupational profile of Indian immigrants entering the United States. It shows that a substantial majority of Indian immigrants are engaged in 'professional and technical' occupations. The percentage share of these professionals amongst all Indian immigrants has increased over the years, conveying that the position of the highly skilled and knowledgeable (apparently all of them HRST) has improved in the Indian immigrant workforce in the US labour market. A plausible explanation of this kind of improvement in the share of HRST in the working immigrant community lies in the fact that "educationwise, Indian immigrants in America have been better equipped with 'human capital' to enter the higher echelons of the US job market than other immigrants". (Khadria 1999a, p.97). For "executive, administrative and managerial' occupations too, their percentage share amongst all Indian immigrants remains substantial. 

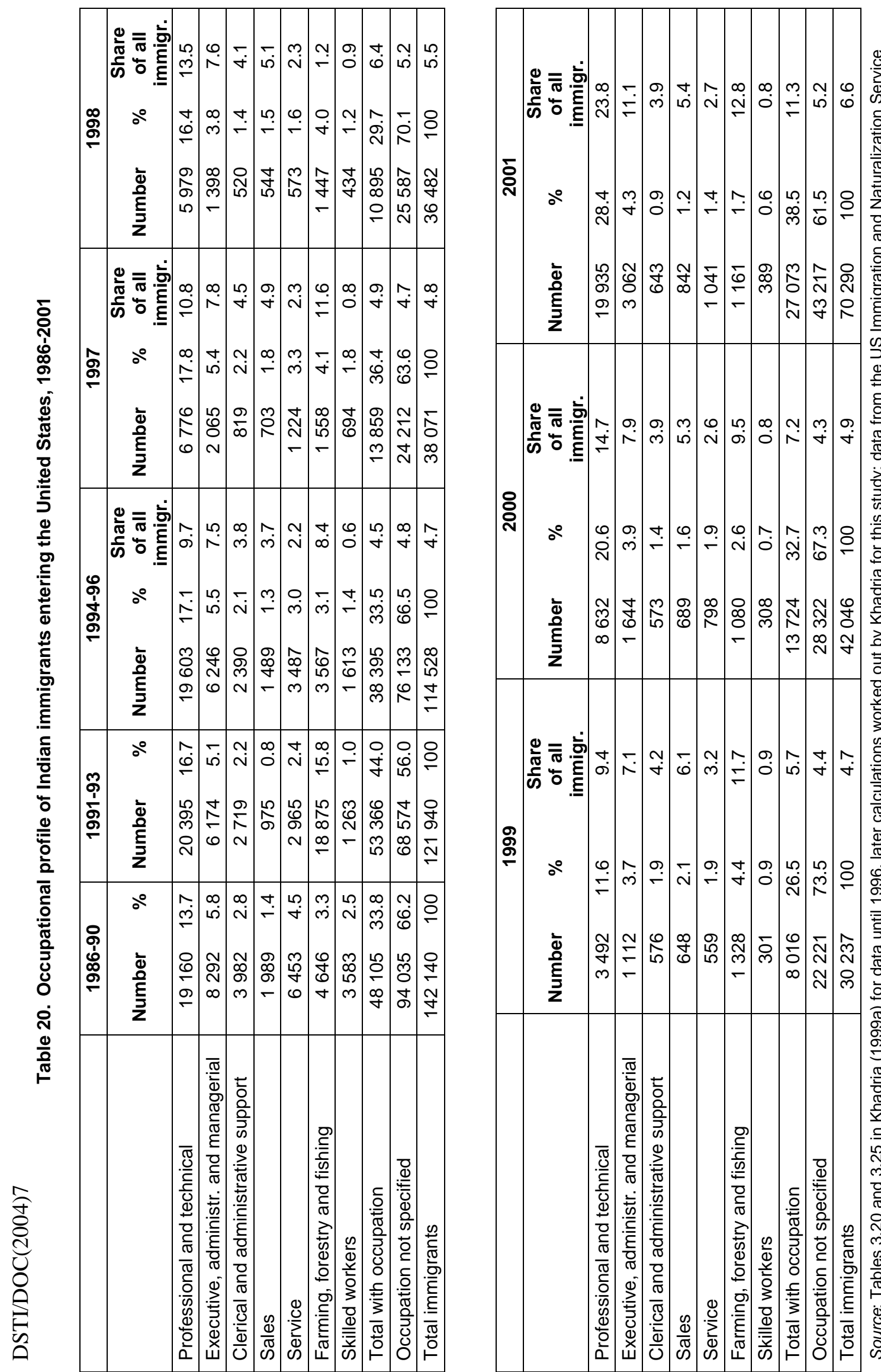

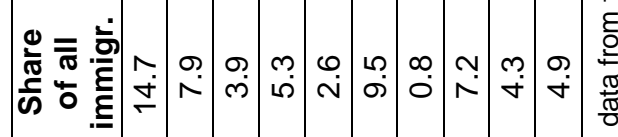

ষ্ণ

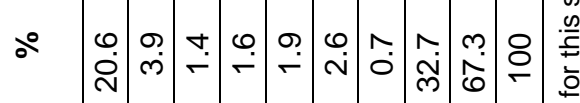

‡

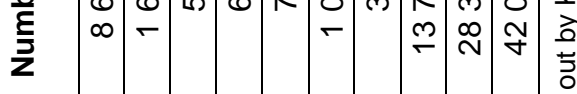

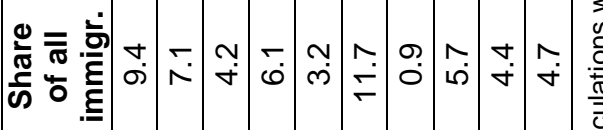

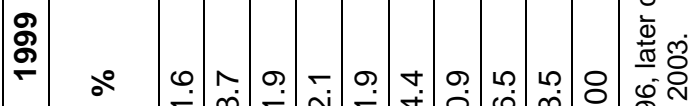

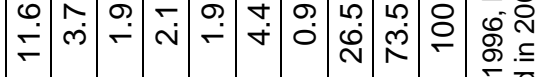

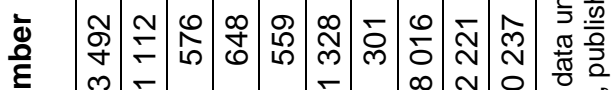
$\infty$ Nิ

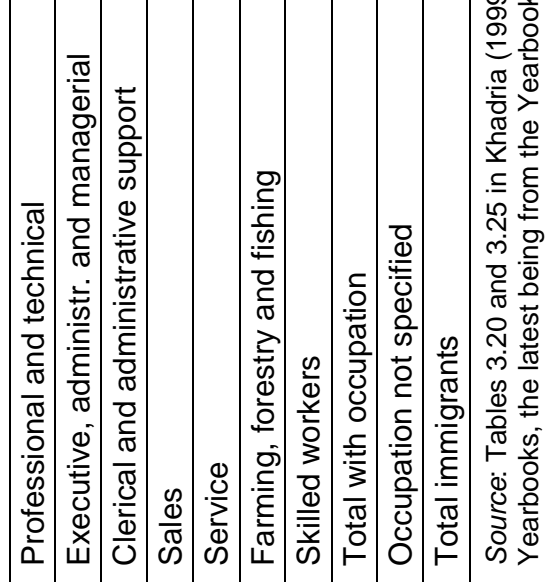


Table 21 provides a summary of published brain-drain estimates from sample surveys conducted in four front-ranking Indian institutes of medical and technical education. According to these surveys, the All India Institute of Medical Sciences (AIIMS) in New Delhi stands at the top of the list of institutions from which more than half the output of graduate doctors $(56 \%)$ has left for greener pastures abroad during 1956-80. The magnitude of brain-drain from three Indian Institutes of Technology has also been substantial with a large proportion of their graduated engineers (ranging between $20 \%$ and 30\%) having left to explore more promising opportunities, particularly in the developed countries.

Table 21. Comparative overview of brain drain estimates of some institution-based surveys

\begin{tabular}{|l|c|c|c|c|}
\hline Indicators & $\begin{array}{c}\text { Indian Institute of } \\
\text { Technology } \\
\text { Bombay, Mumbai }\end{array}$ & $\begin{array}{c}\text { Indian Institute of } \\
\text { Technology } \\
\text { Madras, Chennai }\end{array}$ & $\begin{array}{c}\text { All India Institute } \\
\text { of Medical } \\
\text { Sciences, New } \\
\text { Delhi }\end{array}$ & $\begin{array}{c}\text { Indian Institute of } \\
\text { Technology New } \\
\text { Delhi, New Delhi }\end{array}$ \\
\hline Year of study & 1987 & 1989 & 1992 & 1997 \\
\hline Period covered & $1973-77$ & $1964-87$ & $1956-80$ & $1980-90$ \\
\hline Population size & 1262 & 5942 & 1224 & 2479 \\
\hline Sample size & 501 & 429 & 402 & 460 \\
\hline In India & 179 & 184 & 200 & 316 \\
\hline Out of India & 322 & 245 & 202 & 144 \\
\hline Magnitude of brain drain & $30.8 \%(+/-2 \%)$ & $25-28 \%$ & $56.2 \%(+/-1.3 \%)$ & $23.1 \%(+/-1.5 \%)$ \\
\hline
\end{tabular}

Source: Various Government of India, Department of Science and Technology sponsored institution-based survey studies as cited in Khadria (1999a).

Finally, the World Competitiveness Yearbook 2000 has presented a 47 country ranking of brain drain, which was compiled on the basis of a survey asking whether "well-educated people emigrate or do not emigrate abroad", in which India has been placed forty-second from the top, and sixth from the bottom. India has also been assigned a significance score of 3.291 calculated on a scale between 0 and 10, using a special standard deviation method (SDM) to assign each country a standardised (STD) value or score. ${ }^{15}$ The low ranking and score both mean that India has a high degree of brain drain in terms of well-educated people emigrating abroad. The United States is at the top with a score of 8.524, meaning very few educated Americans emigrate ${ }^{16}$; the United Kingdom's ranking is thirteenth with a score of 6.343 , meaning that some people emigrate. India is better off, relatively speaking, than Venezuela, the Philippines, Russia, Colombia and South Africa, but worse off than Argentina. It is no wonder then that the average per-hour contribution of people employed within India to the production of India's gross domestic product is amongst the lowest in the world (in 1999, a mere 37 cents per capita in India vis-à-vis just below USD 37 in the United States, i.e. one-hundredth). This naturally is a paradox, because Indian HRST employed abroad contribute very high average shares to the GDP of those countries where they are working.

15. Table 8.13 (IMD 2000, p.500): Labor Force Characteristics. For methodology used to arrive at the rankings and the scores, see the chapter on Data Processing Methodology.

16. The United States is the most sought-after destination country with the highest positive net in-migration in the world. See also Khadria (1991). 


\section{DSTI/DOC(2004)7}

\section{Concluding remarks}

In conclusion, it can be said that the Indian data on HRST available from different secondary sources suffer from lack of uniformity, consistency, updating and easy international comparability. Therefore, there is an urgent need for improvement by following suitable methods of data collection to facilitate comparison, ensuring at the same time uniformity and consistency of the data. To this end, there should be a full-time, permanent and centralised mechanism in India to collect and maintain the records of HRST data, which would facilitate easy access and meaningful usage.

A brief review of the data on HRST tells us that there has been an ongoing increase in the number of graduates and diploma holders in professional education during the period between 1991 and 2000. The data on overall stocks of professional postgraduates are not available, though data on postgraduate degree holders in some professional subjects having employment are available from the census data and for a few occupations from secondary sources. There is also no direct availability of stocks of doctorate degree holders. However, these data have been estimated/compiled by adding up the number of doctorate degrees awarded since 1982-83. However, there are a few years for which data on doctorate degrees awarded are not available. HRRD data are exhaustive for the year 1996, with many dimensions, such as education level, sex, sector, specialisation, etc. Data on the degrees of Master's of Business Administration (MBA), Company Secretaries (CS), Charted Accountants (CA), etc. are perhaps available in the respective institutions, but are not widely accessible.

Host country data on immigration of Indian HRST are not easily accessible from India, except for countries like the United States (some are covered in this study), the United Kingdom and only a few others. As far as the Indian sources are concerned, data on out-migration or in-migration of HRST are practically non-existent. In this regard, it could be suggested that steps should be taken to collect migration data (both emigration and immigration) in revised and updated formats through the census, and inter-census data should be collected continuously in given formats. 


\section{BIBLIOGRAPHY}

AIU (Association of Indian Universities) (1997), Selected Statistical Data on Indian Higher Education-I (Data for 1993-94 to 1995-96), Data-Base Unit, Research Division, AIU, New Delhi.

AIU (1998a), Bibliography of Doctoral Dissertations-1993: Natural and Applied Sciences, AIU, New Delhi.

AIU (1998b), Bibliography of Doctoral Dissertations-1994 \& 1995: Physical Sciences - Chemistry, Physics, AIU, New Delhi.

AIU (1999), Bibliography of Doctoral Dissertations-1994 \& 1995: Earth System Sciences - Environmental Sciences, Geology, Geophysics, AIU, New Delhi.

AIU (2000), AIU Status Report, AIU, New Delhi.

AIU (undated), Selected Statistical Data on Indian Higher Education - IV: International Students in Indian Universities, International Education Cell, Student Information Services Division, AIU, New Delhi.

Auriol, L. and J. Sexton (2001), "Human Resources in Science and Technology: Measurement Issues and International Mobility", in OECD (2001), International Mobility of the Highly Skilled, Paris.

Barré, R., V. Hernandez, J-B. Meyer and D. Vinck (eds.) (2003), Scientific Diasporas, IRD, Paris.

Bhagwati, J. N. (1982), "Directly Unproductive Profit-seeking (DUP) Activities", Journal of Political Economy, vol. 90, No. 5, pp. 988-1002.

Bhagwati, J. N. and Partington, M. (eds.) (1976), Taxing the Brain Drain - A Proposal, Amsterdam, North-Holland.

CSO (Central Statistical Organisation) (1999), Annual Survey of Industries: Provisional Results for the Factory Sector 1997-98, CSO, Industrial Statistics Wing, Department of Statistics and Programme Implementation, Ministry of Planning and Programme Implementation, Government of India, Calcutta.

DST (Department of Science and Technology) (1987), Pilot Study on Magnitude and Nature of the Brain Drain of Graduates of the Indian Institute of Technology (IIT), Bombay (now Mumbai), Project by S. P. Sukhatme and I. Mahadevan, DST, Government of India, New Delhi.

DST (1989), Data Base for Brain Drain: Institution-based Study - IIT, Madras, Project by M. S. Ananth, K. Ganesh Babu and R. Natarajan, DST, Government of India, New Delhi.

DST (1992), Pilot Study to Evaluate the Phenomenon of Brain Drain among the Graduates of All India Institute of Medical Sciences, New Delhi, Project by V. Kalra, B. D'Monte, K. Ramachandran and K. R. Sundaram, DST, Government of India, New Delhi. 
DST (1997a), A Study on Brain Drain and Career Profile of IIT New Delhi Graduates, Project by S. G. Deshmukh, K. Ravi Raju and P. N. Rao, DST, Government of India, New Delhi.

DST (1997b), Research and Development Statistics 1994-95, Ministry of Science and Technology, DST, Government of India, New Delhi.

DST (1999a), Research and Development in Industry 1996-97, Ministry of Science and Technology, DST, Government of India, New Delhi.

DST (1999b), Research and Development Statistics 1996-97, Ministry of Science and Technology, DST, Government of India, New Delhi.

DST (2002), Research and Development Statistics 2000-01, Ministry of Science and Technology, DST, Government of India, New Delhi.

The Economic Times (2003), "India has no clear immigration rules," The Economic Times, Jan. 26, 2003, p.15 on 'The Global Indian', and various other issues.

GOI (Government of India) (1966), Education and National Development, Report of the Education Commission (under the Chairmanship of D. S. Kothari) (1964-66), Government of India, New Delhi.

GOI (1995), Census of India 1991, Part III B - B Series, Economic Tables, Vol.-11, India, States and Union Territories, Registrar General and Census Commissioner, New Delhi.

GOI (1998), Indian Students/Trainees Going Abroad 1996-97, Ministry of Human Resource Development, Government of India, New Delhi.

GOI (1999), The Gazette of India, Regd. No.D.L.33004/98, Extraordinary, No.63: PIO Card Scheme, New Delhi, March 30.

GOI (2000a), Indian Labour Statistics 1997, Ministry of Labour, Labour Bureau, Government of India, Shimla.

GOI (2000b), Indian Labour Yearbook 1998, Government of India, Ministry of Labour, Labour Bureau, Shimla/Chandigarh.

GOI (2001), Selected Educational Statistics: 1999-2000, Ministry of Human Resource Development, Government of India, New Delhi.

GOI (2002), Report of the Special Group on Targeting Ten Million Employment Opportunities per Year over the Tenth Plan Period, Planning Commission, Government of India, New Delhi.

Hindustan Times (2003), Report on Prime Minister's Inaugural Speech at the Indian Science Congress in Bangalore, Hindustan Times, 16 Feb. 2003 (and various other issues), New Delhi.

ICCR (Indian Council for Cultural Relations) (2001), Annual Report April 1999 - March 2000, Indian Council for Cultural Relations, New Delhi.

ICWA (Indian Council of World Affairs) (2001), Report of the High Level Committee on the Indian Diaspora, Indian Council of World Affairs, New Delhi. 
IMD (Institute of Management Development) (2000), World Competitiveness Yearbook, Institute of Management Development, Lausanne.

INC (Indian Nursing Council) (2001), Total Number of Nursing Educational Institutions, Total Number of Candidates Admitted in Different Nursing Courses and Total Number of Qualified/Registered Nursing Personnel All Over India (Unpublished Data), Indian Nursing Council, New Delhi.

INS (Immigration and Naturalization Service) (1997), Statistical Yearbook of the INS 1996, US Department of Justice, Immigration and Naturalization Service, Washington, D.C.

Khadria, B. (1989), "The Subsidies Question in Higher Education - Tight-Rope Walking for Public Policy Makers in Developing Countries", Journal of Educational Planning and Administration, vol. 3, Jan. \& April 1989, pp. 43-59.

Khadria, B. (1991), "Contemporary Indian Immigration to the United States - Is the Brain Drain Over?" Revue Européenne Des Migrations Internationales, vol. 7, no. 1, pp. 65-96, Poitiers, France.

Khadria, B. (1999a), The Migration of Knowledge Workers: Second Generation Effects of India's Brain-Drain, Sage Publications, New Delhi.

Khadria, B. (1999b), "Tertiary Education as A Knowledge-Generating Service Industry, and Migration of Knowledge Workers as a Means of Countering the Imbalances of Poverty and Power", The Fifth Biennial Oxford International Conference on Education and Development: Poverty, Power and Partnerships, 9th-13th Sept. 1999, Oxford.

Khadria, B. (2001a), "Shifting Paradigm of Globalization: The Twenty-first Century Transition towards Generics in Skilled Migration from India", International Migration, Special Issue: International Migration of the Highly Skilled, vol. 39, No. 5, pp. 45-71.

Khadria, B. (2001b), "Tracing the Historical Geneses of 'Brain Drain' in Indian Polity, State Policy and Civil Society", Paper presented at the Conference on Citizenship and Those Who Leave - The Politics of Emigration and Expatriation, organised at Centre de Recherches Historiques, E.H.E.S.S. - C.N.R.S., Paris, 6-8 Dec. 2001 (Forthcoming in an edited volume from the University of Paris V).

Khadria, B. (2001c), "Offshore Universities and the Paradox of Factor-Endowment and Factor-Use in Trade-in-Services", paper presented at the Sixth Biennial Oxford International Conference on Education and Development: Knowledge, Values and Policy, 19-21 Sept. 2001, Oxford.

Khadria, B. (2002), "Skilled Labour Migration from Developing Countries: Study on India", International Migration Papers 49, International Labour Office, Geneva.

Khadria, B. (2003), "Case Study of the Indian Scientific Diasporas", chapter 9 in Barré et al. (2003), IRD, Paris.

Khadria, B. (2004), "Migration of Highly Skilled Indians: Case Studies of IT and Health Professionals", STI Working Paper 2004/6, OECD, Paris.

Krueger, A.O. (1974), “The Political Economy of Rent-Seeking Society", American Economic Review, vol. 64 , No. 3, pp. 291-303.

Majumdar, T. (1998), "Education: Uneven Progress, Difficult Choices", in H. Karlekar (ed.), Independent India: The First Fifty Years, New Delhi, Oxford University Press. 
McKinsey and NASSCOM (1999), NASSCOM - McKinsey Study Report, National Association of Software and Service Companies, New Delhi.

MCI (Medical Council of India) (2002), Number of Doctors Possessing Recognised Medical Qualification (under IMC Act) and Registered with State Medical Councils from the Years 1986 to 2002 (Unpublished Data), Medical Council of India, New Delhi.

NASSCOM (National Association of Software and Service Companies) (2002), Strategic Review 2002, Chapter 5: 'Knowledge Professionals', National Association of Software and Service Companies, New Delhi, pp. 63-82.

NSF (National Science Foundation) (2000), Science and Engineering Indicators 2000, NSF, Arlington, VA.

NSF (2002), Science and Engineering Indicators 2002, Arlington, VA.

NSSO (National Sample Survey Organisation) (1998), Attending an Educational Institution in India: Its Level, Nature, and Cost, NSS - Fifty-second Round: July 1995-June 1996, Report No. 439(52/25.2/1), October, National Sample Survey Organisation, Department of Statistics, Government of India, Calcutta.

NSSO (2000), Employment and Unemployment in India 1999-2000: Key Results, NSS - 55 ${ }^{\text {th }}$ Round, Report No. 455(55/10/1), December, National Sample Survey Organisation, Ministry of Statistics and Programme Implementation, Government of India, Calcutta.

OECD (Organisation for Economic Co-operation and Development) (1995), Manual on the Measurement of Human Resources Devoted to S\&T (the "Canberra Manual"), Eurostat/OECD, OCDE/GD(95)77, Paris.

OECD (2001), International Mobility of the Highly Skilled, OECD, Paris.

OECD (2002), The Measurement of Scientific and Technological Activities. Frascati Manual 2002: Proposed Standard Practice for Surveys on Research and Experimental Development, OECD, Paris.

UGC (University Grants Commission) (2001), Annual Report 1999-2000, University Grants Commission, New Delhi.

World Focus (2001), Special Issue on Indian Diaspora - Its Positive Contribution, World Focus No. 255, March 2001. 